$\Omega$

(

\title{
CRREL
}

Axial Double-Ball Test Versus the Uniaxial Unconfined Compression

O) Test for Measuring the Compressive Strength of Freshwater and Sea Ice

Austin Kovacs

December 1993

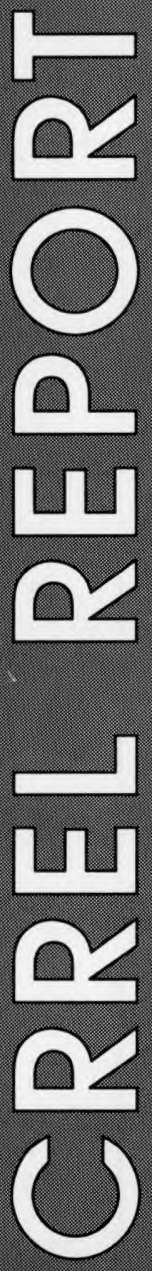
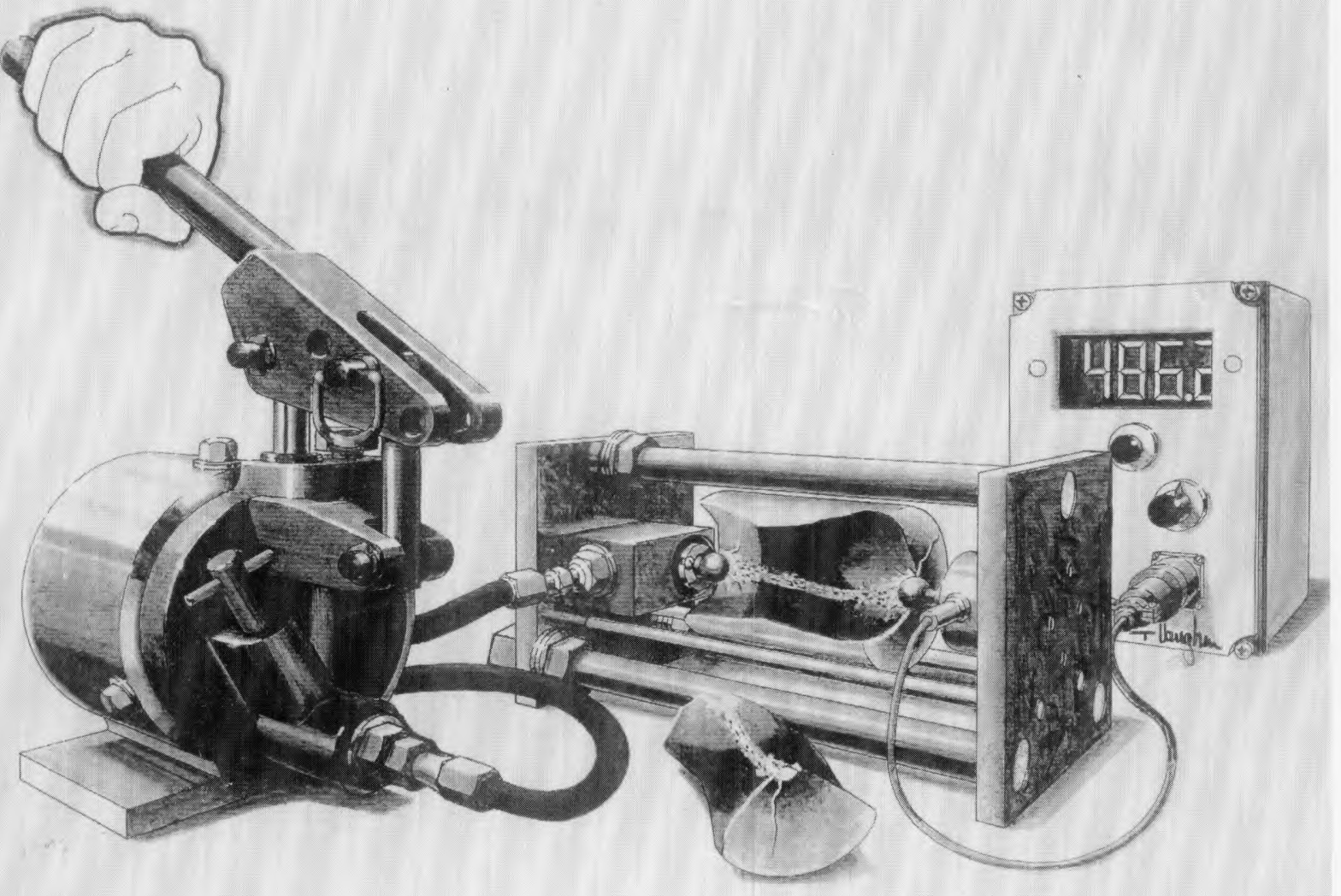


\begin{abstract}
Axial double-ball load tests were made on freshwater ice and first-year and multiyear sea ice. From this simple test method the apparent unconfined compressive strength of the ice was determined. These strength results were compared with those obtained from the complex and costly uniaxial unconfined compression test made on similar ice at a strain rate of $10^{-3} \mathrm{~s}^{-1}$. The scatter in the test data and the average ice strength obtained from both test methods were similar. The findings indicate that the expedient axial double-ball load test is well suited for determining the unconfined compressive strength of ice, especially in the field where the demanding sample preparation requirements needed for unconfined compression test samples cannot be met.
\end{abstract}

For conversion of SI metric units to U.S./British customary units of measurement consult Standard Practice for Use of the International System of Units (SI), ASTM Standard E380-89a, published by the American Society for Testing and Materials, 1916 Race St., Philadelphia, Pa. 19103. 


\section{CRREL Report 93-25}

US Army Corps

of Engineers

Cold Regions Research \& Engineering Laboratory

\section{Axial Double-Ball Test Versus the Uniaxial Unconfined Compression Test for Measuring the Compressive Strength of Freshwater and Sea Ice}

Austin Kovacs 


\section{PREFACE}

This report was prepared by Austin Kovacs, Research Civil Engineer, Applied Research Branch, Experimental Engineering Division, U.S. Army Cold Regions Research and Engineering Laboratory. The author acknowledges the field and laboratory assistance of John Kalafut and Richard Roberts of CRREL. Dr. Gordon F.N. Cox, formerly of CRREL, now at Amoco Production Company, donated some of the multiyear sea ice samples, and Dr. Erland M. Schulson of Dartmouth College donated some of the freshwater ice samples.

The contents of this report are not to be used for advertising or commercial purposes. Citation of brand names does not constitute an official endorsement or approval of the use of such commercial products. 


\section{CONTENTS}

Preface
Introduction . .
Axial double-ball test
Ice tested
Test results
Freshwater ice
Discussion
Literature cited sea ice

\section{ILLUSTRATIONS}

Figure

1. Axial DB test apparatus in use at CRREL ........................................................... 2

2. Axial DB test jig with an LVDT configured to measure hydraulic ram travel vs. time

3. Logging sea ice core in the field ................................................................................. 3

4. Digital measuring device ......................................................................................... 4

5. Failure concept for ball loading of a test sample ........................................................ 4

6. Example of failed ice samples loaded in the axial DB test system .......................... 5

7. Multiyear sea ice test sample that split into three segments at failure ..................... 5

8. Multiyear sea ice sample that failed by spalling ....................................................... 5

9. Shape factor vs. ice core diameter ........................................................................ 6

10. Example of failed freshwater ice showing an axial "pipe" of concentrated fine cracks, en echelon cracks and numerous "cloud" cracks

11. Dynamic modulus test results for polar firn and ice and the average test data from this study ............................................................................................. 8

12. Freshwater ice unconfined compressive strength vs. grain size............................... 9

13. 1966 view looking down the inclined drift at Camp Century, Greenland ............... 10

14. Camp Century, Greenland, firn and ice grain size vs. density ............................... 10

15. Camp Century, Greenland, firn and ice unconfined compression strength vs.

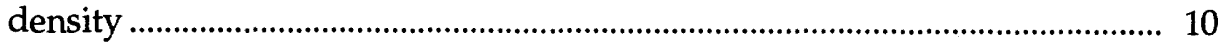

16. Multiyear sea ice unconfined compressive strength vs. porosity ............................. 12

17. Horizontal first-year sea ice unconfined compressive strength vs. porosity ........... 14

18. Horizontal first-year sea ice unconfined compressive strength vs. the angle between the applied load and the predominant c-axis direction ..................... 14

19. Vertical first-year sea ice unconfined compressive strength vs. porosity ................ 16 


\section{TABLES}

Table

1. Test data for $5-\mathrm{mm}$ grain size freshwater ice at $-8^{\circ} \mathrm{C}$

2. Axial double-point unconfined compressive strength vs. density of freshwater ice with a grain size of $3.5 \mathrm{~mm}$.................................................................... 9

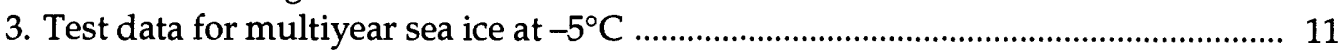

4. Test data for first-year sea ice loaded perpendicular to the c-axes at $-16^{\circ} \mathrm{C}$............ 12

5. Test data for first-year sea ice loaded parallel to the c-axes ................................... 13

6. Test data for first-year sea ice with aligned c-axes, loaded vertically ....................... 13

7. Test data for melt pond sea ice, with random crystal c-axis orientations, loaded vertically 


\title{
Axial Double-Ball Test Versus the Uniaxial Unconfined Compression Test for Measuring the Compressive Strength of Freshwater and Sea Ice
}

\author{
AUSTIN KOVACS
}

\section{INTRODUCTION}

Ice formed in nature is almost always structurally anisotropic. An exception is the equiaxed granular ice found at select depths in polar ice caps, where the c-axes of the ice crystals are randomly oriented. This ice has been found to exhibit the same strength properties irrespective of the direction of the applied load (Kovacs et al. 1969). Freshwater ice is often considered to be a single-phase material; however, it frequently contains numerous gas bubbles of varying size that affect ice strength. Sea ice is truly a multiphase material composed of solid freshwater ice, liquid brine and gas. Like freshwater ice the sea ice structure can consist of granular and columnar crystals, which can vary in width, length and structure with ice sheet depth. Most natural ice is heterogeneous and anisotropic; therefore, the structure of the ice and the direction of the load applied to it, as well as its temperature and the rate of load application, must be factored into the interpretation of load test results.

Many test techniques have been applied to understanding the strength characteristics of ice, with mixed results. The most-performed test is theuniaxial unconfined compression test. This is a deceptively simple test that has not always been done "correctly" because of the difficult and labor-intensive sample preparation required. In addition, a stiff testing machine with sample load or strain rate feedback control is needed. Another issue still being reviewed is the preferred contact that should exist between the test sample and the loading apparatus. To help resolve some of the problems and to attempt to develop a standard test procedure, the International Association of Hydraulic Research Committee on Ice Problems devised guidelines for performing the uniaxial unconfined compression test on ice (Schwarz et al. 1981). Nevertheless, sample size and platen contact conditions are still a topic of review (Kuehn et al. 1992), and the equipment required to make high-quality icesamples and the heavy loading apparatus needed to perform the uniaxial unconfined compression test pose logistic problems when field testing is desired.

To circumvent the demanding samplepreparation requirements and heavy equipment needed to perform uniaxial unconfined compression tests in the field, Kovacs (1978) explored the feasibility of using a simple lightweight axial double-ball load test device for determining the unconfined compressive strength $\sigma_{\mathrm{c}}$ of snow and ice in the Antarctic. This evaluation led to another study in which sea ice strength was evaluated vs. loading ball size, temperature and ice density (Kovacs 1985). From this study the unconfined compressive strength determined with the use of $16-\mathrm{mm}$ diameter loading balls was found to agree with the uniaxial unconfined compressive strength obtained at a strain rate of $10^{-3} \mathrm{~s}^{-1}$.

\section{AXIAL DOUBLE-BALL TEST}

The CRREL axial double-ball (axial DB) test system consists of a test frame, a manually operat- 


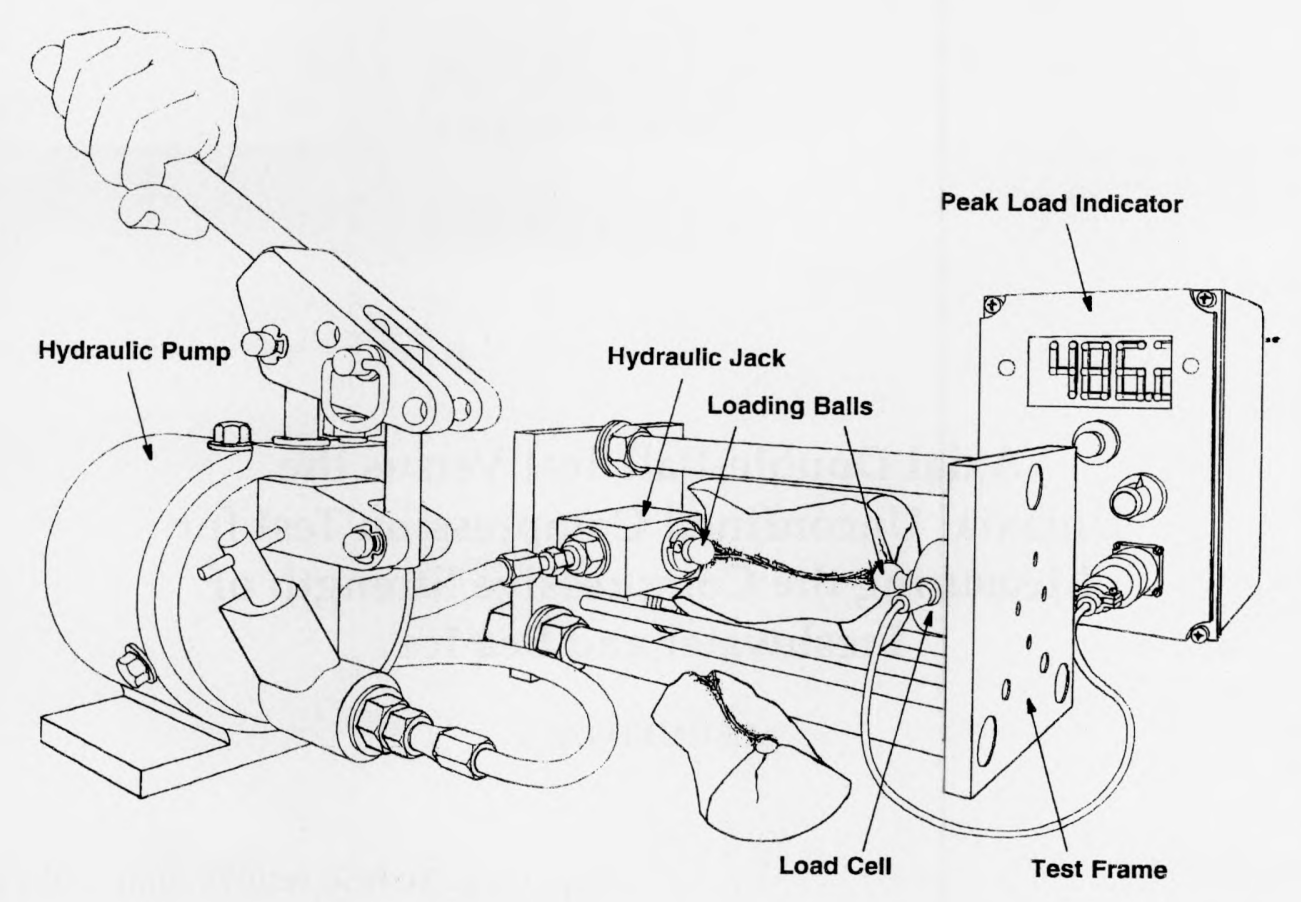

Figure 1. Axial DB test apparatus in use at CRREL.

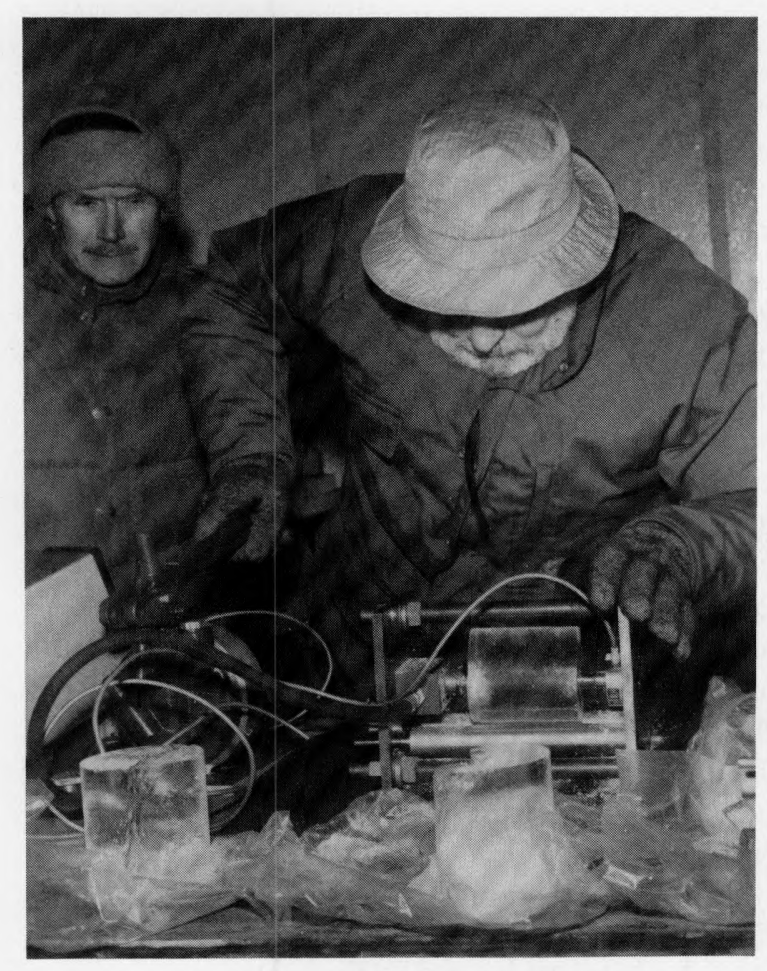

ed hydraulic pump and ram, and a digital load indicator (Fig. 1). The test frame consists of two upright stainless steel plates. The distance between the plates is adjustable to accommodate ice samples of different lengths. After adjustment the plates are locked parallel into a rigid structure by tightening bolts. Totheinside of one plate is mounted a hydraulic ram, and on the opposite plate is fastened a load cell. On the load cell and on the hydraulic ram are mounted load balls. To support the ice sample, two parallel rods, spaced about 3 $\mathrm{cm}$ apart, extend between the plates. These rods can be adjusted up or down to accommodate ice samples of different diameters to ensure that the load balls are in line with the axis of the ice sample. Thehydraulichand pump wassized toensure that 
Figure 2. Axial DB test jig with an LVDT configured to measure hydraulic ram travel vs. time. The arrow points to the LVDT motion shaft. The test sample is sea ice.

Figure 3. Logging sea ice core in the field. The corelength is first measured. Small holes are then drilled about $2-3 \mathrm{~cm}$ deep into the core side at 20-cm increments, and a thermistor is inserted in each hole to determine the in situ temperature of the ice sheet. The core is next cut into lengths using the cutoff saw on the right, and the axial length of the ice cylinder is determined (in this case using a dial gauge measurement jig located beside the notebook). The sample is next weighedon an electronic balance and tested in the axial $D B$ system. The fractured ice pieces are then placed in plastic bags for later melting and salinity measurements.
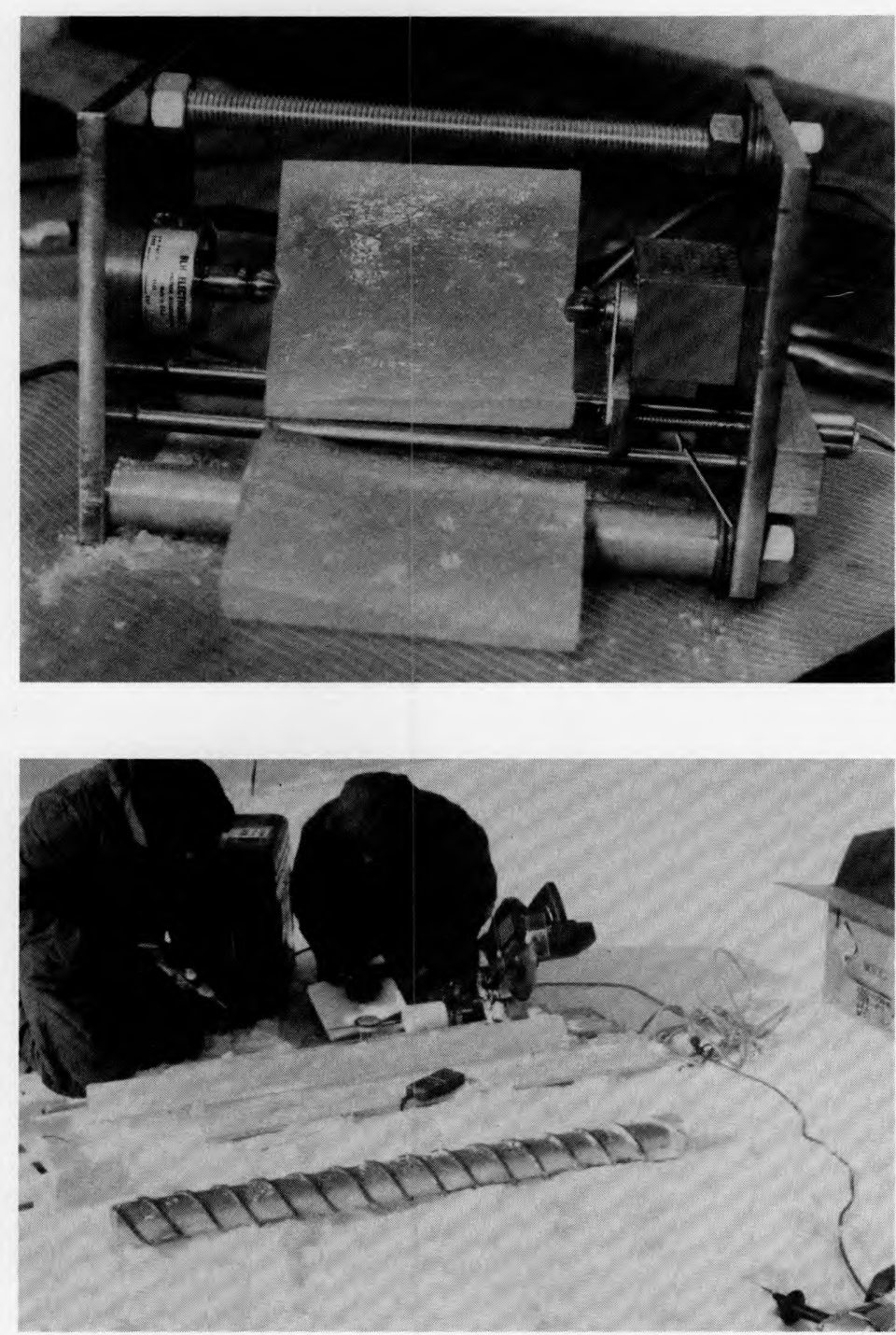

one swift downward stroke of the pump handle would quickly drive the ball, mounted on the face of the hydraulic ram, sufficiently deep into the ice to cause it to split. For several tests a linear potentiometer was installed for monitoring the ram travel and the time to peak load (Fig. 2).

Test sample preparation is straightforward. Previous testing revealed that for ice the sample length must be 1.05-1.1 times the sample diameter. The former length is preferred. Ice samples should have reasonably parallel ends, which need not be smooth. This may be achieved with use of a miter box or, as we prefer, with the use of a carpenter's power cutoff saw (Fig. 3). With this device, ice core may be quickly cut to length in the field and then weighed on a small battery-powered electronicscale. Thesamplediameter once determined, using a pi tape, should remain constant for the core barrel used. The sample length may be determined with a caliper. However, we prefer a digital electronic displacement measurement device for measuring the sample length at the axis of the ice core. The simple measurement jig made for field use is shown in Figure 4. This measurement technique is very accurate and compensates for sampleends not being parallel should that occur when a hand saw is used to cut core to length. An accurate length measurement is most needed for the determination of sample volume but also for use in the axial DB strength equation.

The test procedure is also straightforward. An ice sample is set onto the support rods, the ram is moved forward until the balls contact the ice, and the ram is then propelled forward with one downstroke of the hydraulic pump handle. When the balls are forced against the ice, stresses develop in 


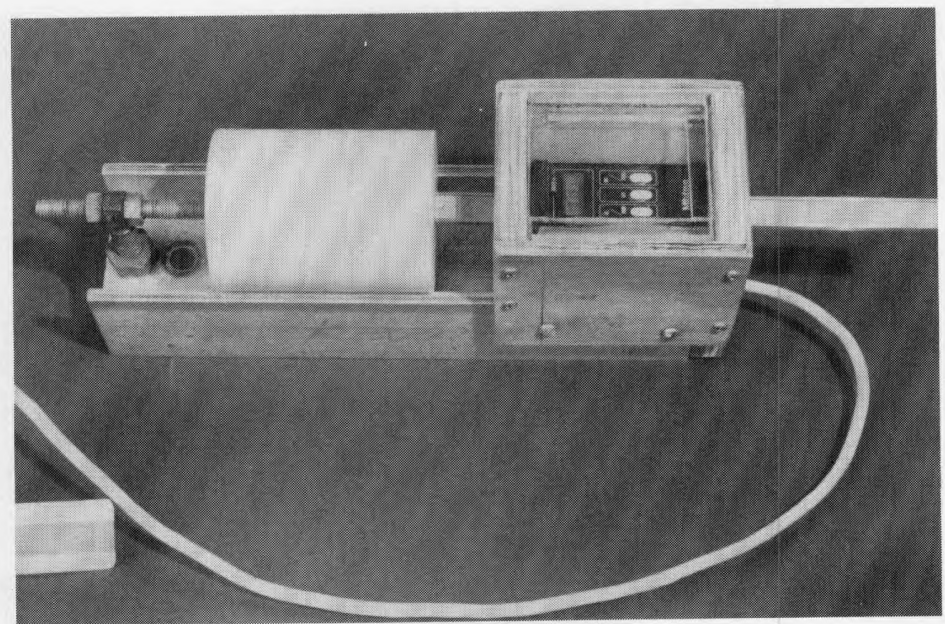

a. Determining the axial length of an ice core.

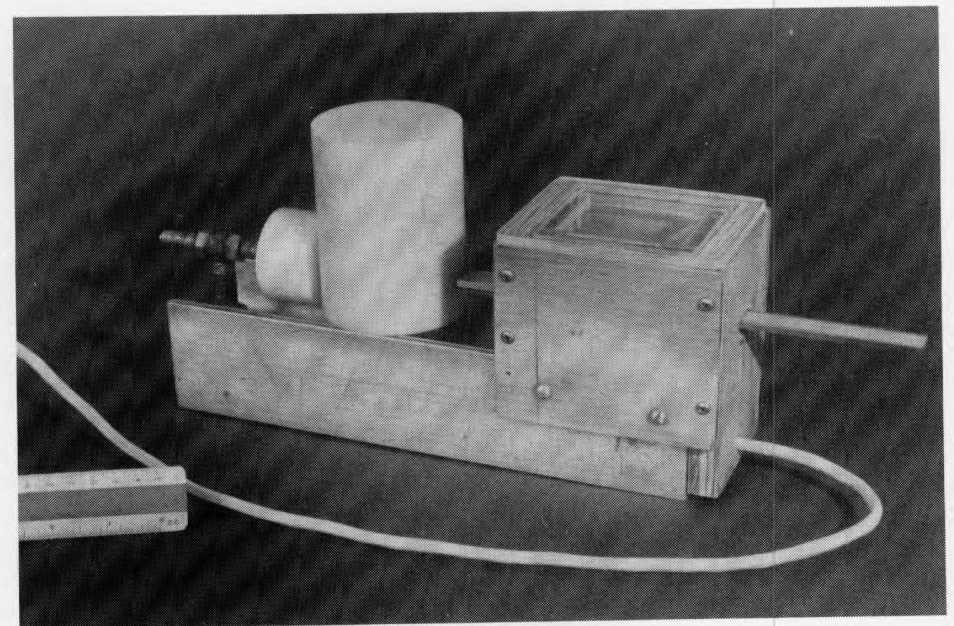

b. Measuring the core diameter.

Figure 4. Digital measuring device. The cable provides power to a small blanket heater needed to prevent the crystal display from freezing.

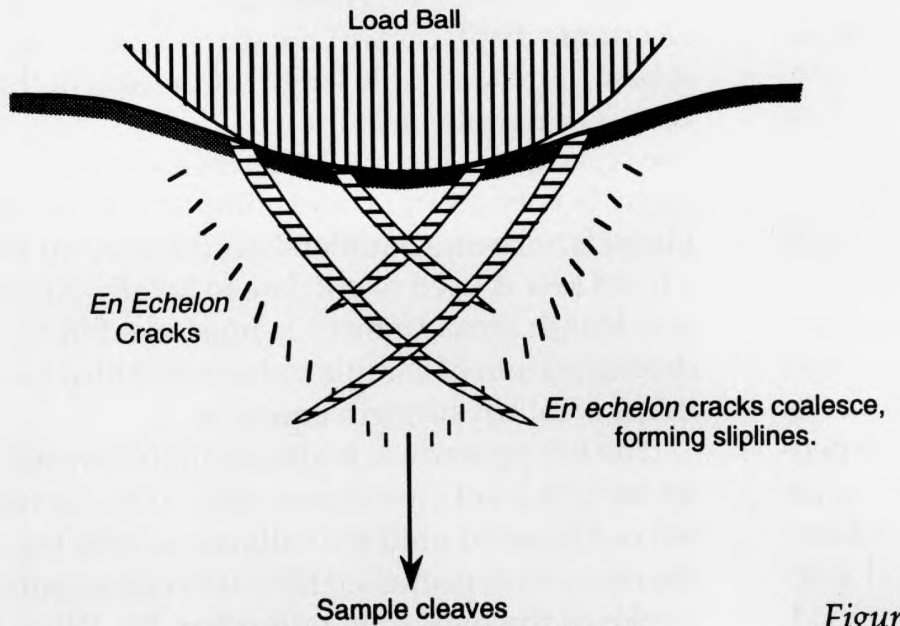

Figure 5. Failure concept for ball loading of a test sample as postulated by Reichmuth (1968). 
the ice at the contact zone. In the freshwater ice sample shown in Figure 1, cracks have developed in the stress zone, giving the ice a cloudy white appearance at each end. The crack formation sequence has been described by Reichmuth (1968). He speculated that en echelon cracks first form in the stressed zone (Fig. 5). As the cracks multiply, they coalesce and form sliplines. Sample failure

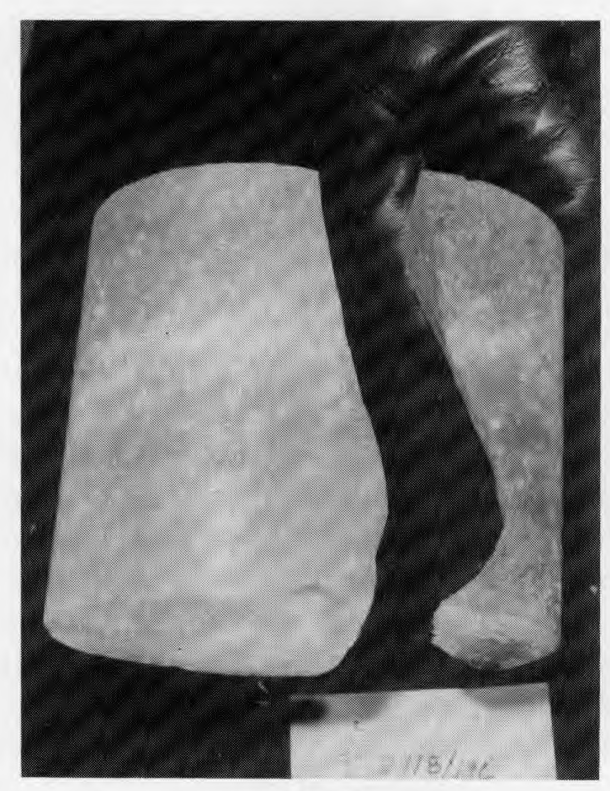

a. Sea ice. occurs when a critical stress level is reached, which most often causes a crack to propagate along the axis of the sample. The peak force at failure, as sensed by the load cell, is displayed on the highspeed digital peak-load indicator. The unique feature of this test procedure is that ice may be tested shortly after being removed from the core barrel. Failed ice samples typically split in two (Fig. 6) or three pieces (Fig. 7), but four pieces sometimes occur. Spalling also occurs in conjunction with axial splitting and at times as the sole fracture (Fig. 8 ). The latter event renders the test unacceptable.

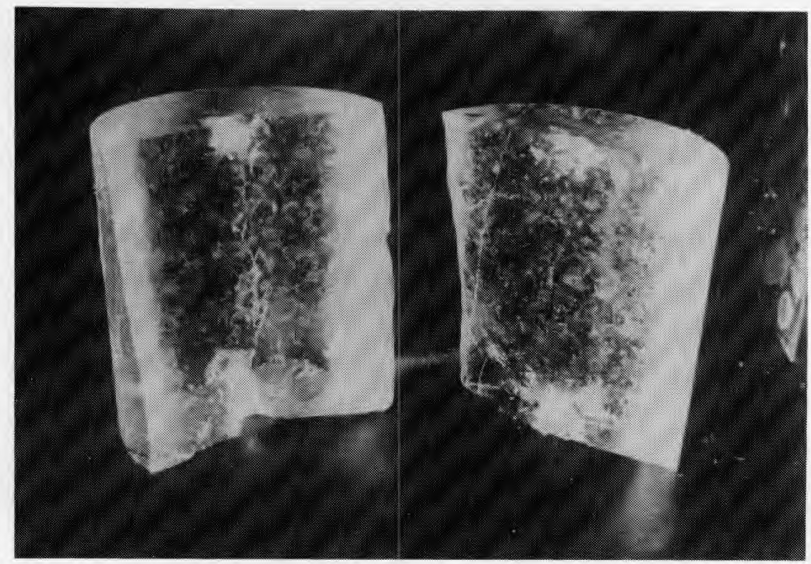

b. Freshwater ice.

Figure 6. Example of failed ice samples loaded in the axial DB test system. Note the interesting nonlinear split in the sea ice sample and the lacy crack "pipe" visible at the center of the right freshwater ice piece. "Cloud" cracks are also visible in the freshwater ice.

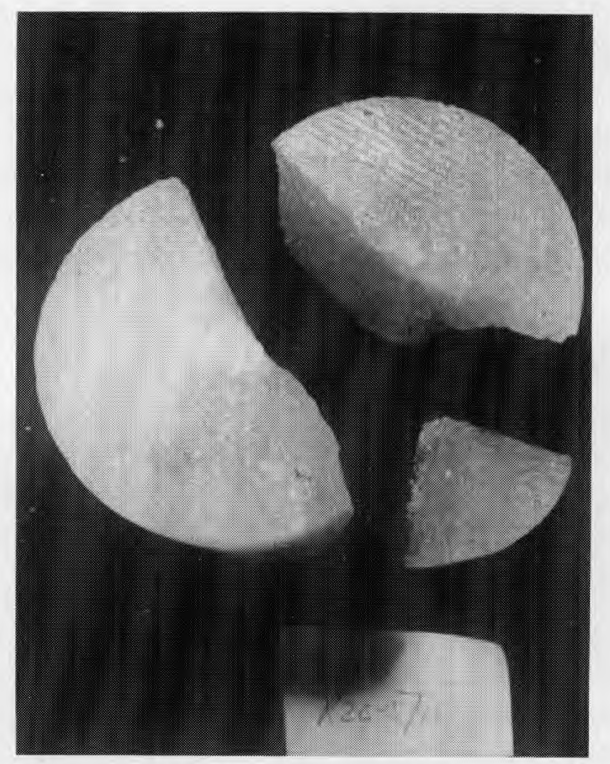

Figure 7. Multiyear sea ice test sample that split into three segments at failure.

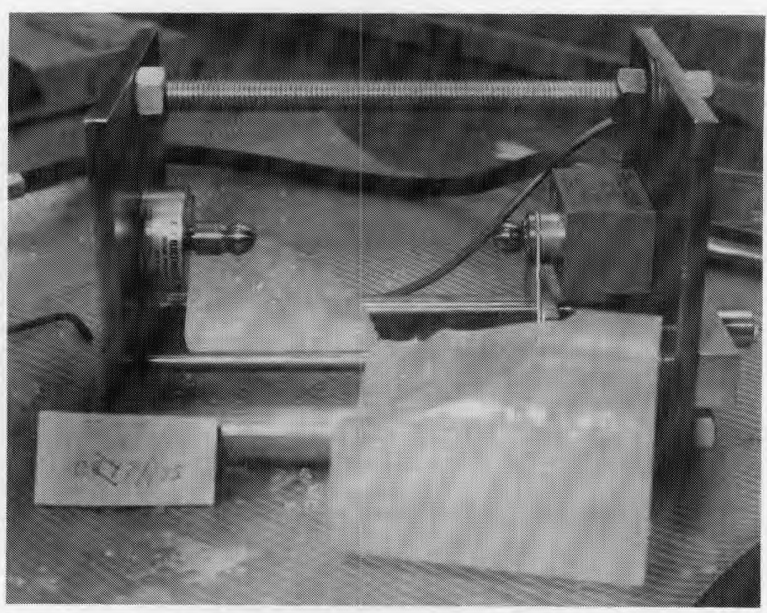

Figure 8. Multiyear sea ice sample that failed by spalling. 


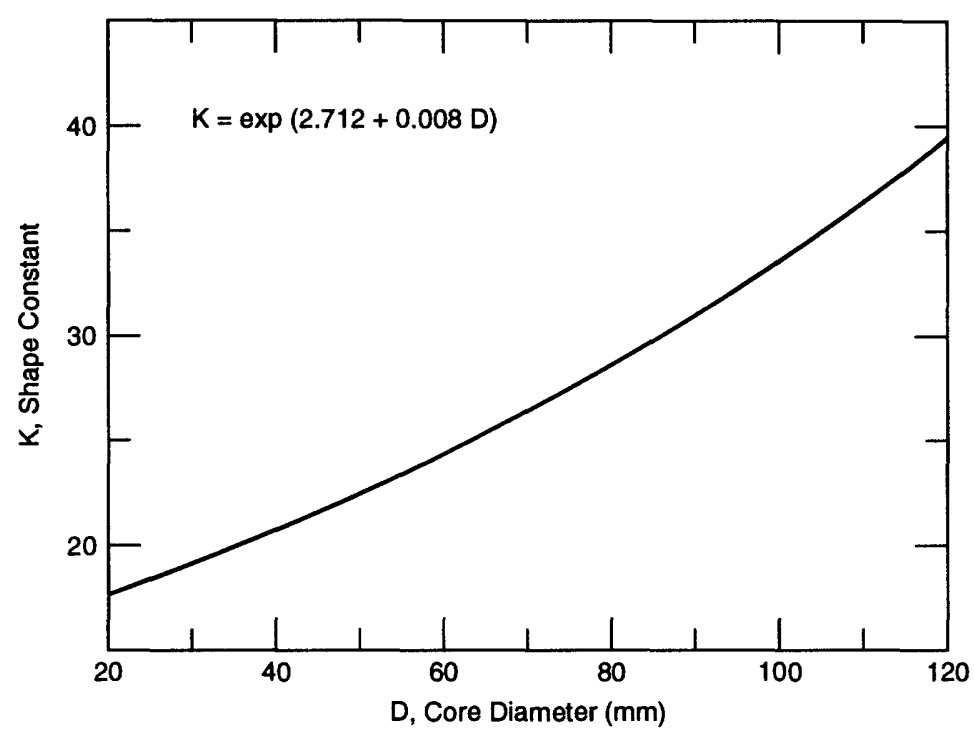

Figure 9. Shape factor vs. ice core diameter. (After Kovacs 1978.)

This type of failure may be the result of a slip-line crack, shown in Figure 5, propagating laterally.

The equation for determining $\sigma_{\mathrm{c}}$ from the axial DB test is (Kovacs 1978)

$$
\sigma_{\mathrm{c}}=\frac{K P}{L^{2}}
$$

where $K=$ a shape constant

$$
\begin{aligned}
& P=\text { peak force }(\mathrm{lbf}) \\
& L=\text { sample length }(\mathrm{in} .) .
\end{aligned}
$$

The shape constant varies with sample diameter and is determined as shown in Figure 9. $K$ is used to normalize the peak force resulting from the testing of samples with different diameters.

\section{ICE TESTED}

Laboratory-grown freshwater ice and natural first-year and multiyear sea ice were tested. Laboratory ice was made at CRREL using a procedure described by Cole (1979) and at the Ice Research Laboratory (IRL) of the ThayerSchool of Engineering, Dartmouth College, using a modified Cole procedure (Schulson 1990). The CRREL-grown ice, made in $\sim 70$-mm-diameter molds, had a mean density of $0.904 \mathrm{Mg} / \mathrm{m}^{3}$ and a related porosity of $\sim 1.4 \%$. The equiaxed grains had a mean diameter of $3.5 \mathrm{~mm}$. The same ice was being used at IRL in an assessment of the effect of grain size on the uniaxial $\sigma_{c}($ Cannon 1985, Schulson 1990). This ice was made in $\sim 82$-mm-diameter molds and contained grains having a mean size of $5 \mathrm{~mm}$. The ice had a preferred higher density of $\sim 0.912 \mathrm{Mg} / \mathrm{m}^{3}$ and a lower porosity of $\sim 0.6 \%$.
The multiyear sea ice tested with the axial DB loading system was collected in the Beaufort Sea by Cox et al. (1984). They made uniaxial unconfined compression tests on the same source ice at CRREL using right cylinders having a machined diameter of $102 \mathrm{~mm}$. We tested samples at CRREL using the as-cored diameter of $\sim 105 \mathrm{~mm}$.

The first-year sea ice cores were obtained from large 1.2-m-square blocks of ice removed from the 1.8-m-thick sea ice in Stefanson Sound, Alaska. The ice cores were mined from the ice block at the samedepth in both the vertical $\left(0^{\circ}\right)$ and horizontal $\left(90^{\circ}\right)$ plane of the ice sheet. In the latter the ice cores were taken paralle $190^{\circ}-0^{\circ}$ and perpendicular $90^{\circ}-$ $90^{\circ}$ to the well-aligned horizontal c-axes of the columnar ice crystals. The mean crystal size was about $11 \mathrm{~mm}$. The 77-mm-diameter ice cores were cut to length and tested in a shed on shore.

Vertical ice cores were also obtained from the first-year sea ice in a refrozen melt pool in a multiyear floe and from the fast ice in Stefanson Sound.

\section{TEST RESULTS}

\section{Freshwater ice}

Six ice cylinders were provided from the IRL at Dartmouth College. From these cylinders, 12 samples were cut. Each had a length of $\sim 102 \mathrm{~mm}$ and a diameter of $91.4 \mathrm{~mm}$. One of the tested samples is shown in Figure 10. Note the crushed zone at each end of the ice cylinder and what appears to be en echelon cracks extending below the top crushed zone. The fractured ice surface is laced with crack damage, and there is a vertical "pipe" of highly fractured ice containing a fine lacework of cracks. 
Figure 10. Example offailed freshwaterice showing an axial "pipe" of concentrated fine cracks, en echelon cracks (one in front of thearrow) and numerous "cloud" cracks that may have formed at crystal boundaries within the ice.

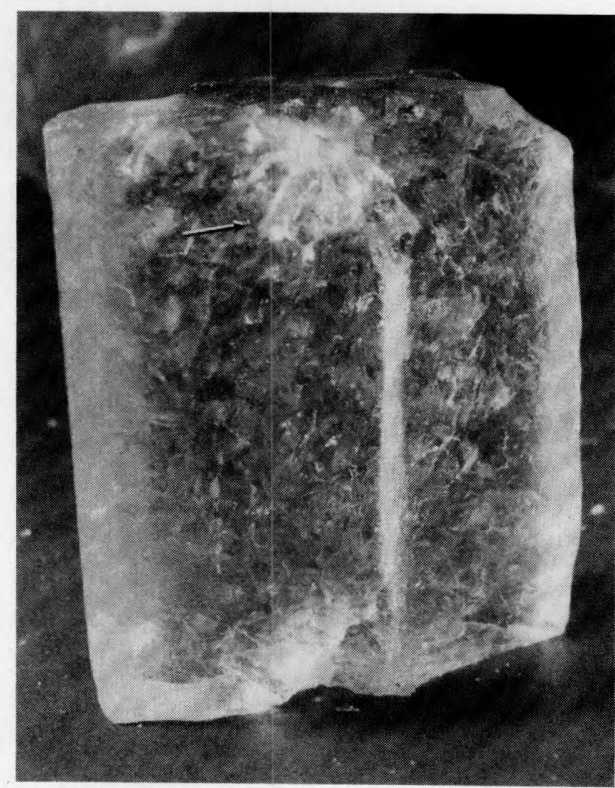

Table 1. Test data for $5-\mathrm{mm}$ grain size freshwater ice at $-8^{\circ} \mathrm{C}$.

\begin{tabular}{|c|c|c|c|c|c|c|c|c|}
\hline \multirow{2}{*}{$\begin{array}{c}\text { Sample } \\
\text { no. }\end{array}$} & \multirow{2}{*}{$\begin{array}{l}\text { Specific } \\
\text { gravity }\end{array}$} & \multicolumn{2}{|c|}{ Velocity $(\mathrm{m} / \mathrm{s})$} & \multirow{2}{*}{$\begin{array}{c}\text { Poisson's } \\
\text { ratio }\end{array}$} & \multirow{2}{*}{$\begin{array}{r}\text { Young's } \\
\text { modulus } \\
(\mathrm{GPa})\end{array}$} & \multirow{2}{*}{$\begin{array}{l}\text { Shear } \\
\text { modulus } \\
(\mathrm{GPa})\end{array}$} & \multirow{2}{*}{$\begin{array}{c}\text { Volume } \\
\text { rigidity } \\
\text { (GPa) }\end{array}$} & \multirow{2}{*}{$\begin{array}{c}\sigma_{c} \\
(M P a\end{array}$} \\
\hline & & $P$ wave & Swave & & & & & \\
\hline $1 \mathrm{~L}$ & 0.910 & 3845 & 1728 & 0.374 & 7.5 & 2.7 & 9.8 & 7.81 \\
\hline 1R & 0.912 & 3817 & 1629 & 0.389 & 6.7 & 2.4 & 10.0 & 7.03 \\
\hline $2 \mathrm{~L}$ & 0.913 & 3799 & 1697 & 0.375 & 7.2 & 2.6 & 9.7 & 6.44 \\
\hline $2 \mathbf{R}$ & 0.912 & 3822 & 2001 & 0.311 & 9.6 & 3.6 & 8.5 & 4.15 \\
\hline $3 \mathrm{~L}$ & 0.909 & 3811 & 1704 & 0.375 & 7.3 & 2.6 & 9.7 & 4.66 \\
\hline $3 \mathbf{R}$ & 0.913 & 3784 & 1680 & 0.377 & 7.1 & 2.6 & 9.6 & 5.18 \\
\hline $4 \mathrm{~L}$ & 0.915 & 3761 & 1689 & 0.374 & 7.2 & 2.6 & 9.5 & 5.00 \\
\hline $4 \mathrm{R}$ & 0.914 & 3781 & 1660 & 0.381 & 7.0 & 2.8 & 10.8 & 5.12 \\
\hline $5 \mathrm{~L}$ & 0.908 & 3812 & 1703 & 0.375 & 7.2 & 2.6 & 9.7 & 4.42 \\
\hline $5 \mathbf{R}$ & 0.913 & 3818 & 1854 & 0.346 & 8.4 & 3.1 & 9.1 & 8.06 \\
\hline $6 \mathrm{~L}$ & 0.914 & 3819 & 1984 & 0.315 & 9.5 & 3.6 & 8.5 & 5.54 \\
\hline $6 \mathbf{R}$ & 0.913 & 3812 & 1993 & 0.284 & 9.5 & 4.6 & 8.5 & 5.29 \\
\hline Avg & 0.912 & 3807 & 1765 & 0.358 & 7.9 & 2.9 & 9.5 & 5.72 \\
\hline
\end{tabular}

The $-8^{\circ} \mathrm{C}$ test results are listed in Table 1 . The average $\sigma_{\mathrm{c}}$ strength was $5.72 \mathrm{MPa}$, which needs to be adjusted to $-10^{\circ} \mathrm{C}$, the temperature at which 10 right cylinders of the same ice type were tested, at the IRL, in uniaxial unconfined compression.* Schulson stated that the IRL tests gave a mean ice strength of $5.8 \mathrm{MPa}$ at a strain rate of $10^{-3} \mathrm{~s}^{-1}$.

To adjust $\sigma_{\mathrm{c}}$ for temperature, a correction factor based on the analysis of Kovacs et al. (1977) was used. They found that $\sigma_{c}$ for snow and ice changed at a rate of $\sim 0.075 \mathrm{MPa} /{ }^{\circ} \mathrm{C}$. This value is in good agreement with the work of Butkovich (1954) on lake ice, Wolfe and Thiem (1964) on river ice, Kovacs (1978) on multiyear sea ice and Brown and

* Personal communication, Dr. Erland Schulson, Dartmouth College.
McKittrich (1992) on a single crystal of freshwater ice. These authors found $\sigma_{\mathrm{c}}$ to increase, at temperatures below about $-10^{\circ} \mathrm{C}$, at a rate of $0.074,0.08$, 0.07 and $0.065 \mathrm{MPa} /{ }^{\circ} \mathrm{C}$, respectively. Bender $(1957)$ proposed the following empirical expression to account for the change in $\sigma_{\mathrm{c}}$ with temperature:

$$
\sigma_{\mathrm{c}_{2}} / \sigma_{\mathrm{c}_{1}}=\left(\left|T_{2}\right| /\left|T_{1}\right|\right)^{0.16}
$$

where $\sigma_{\mathrm{c}_{1}}$ and $\sigma_{\mathrm{c} 2}$ are the $\sigma_{\mathrm{c}}$ strengths at temperatures $T_{1}$ and $T_{2}$, respectively. Based on the findings of the above-referenced authors, this equation provides a strength correction that is too high. Changing the exponent to 0.13 would bring the Bender equation into good agreement with a $\sigma_{c}$ strength change vs. temperature of $0.075 \mathrm{MPa} /{ }^{\circ} \mathrm{C}$.

When this temperature correction is applied to 
the average axial $\mathrm{DB} \sigma_{\mathrm{c}}$ value of $5.72 \mathrm{MPa}$ at $-8^{\circ} \mathrm{C}$, it increases to $5.87 \mathrm{MPa}$ at $-10^{\circ} \mathrm{C}$. Clearly the average axial DB strength is in excellent agreement with the average uniaxial $\sigma_{\mathrm{c}}$ value $(5.8 \mathrm{MPa})$ provided by Schulson for the IRL tests. The two independent test techniques on the same ice type show that the simple axial DB test provides comparable $\sigma_{c}$ values to those obtained in the laboratory at $10^{-3} \mathrm{~s}^{-1}$ using highly sophisticated testing equipment and sample preparation techniques.

Prior to axial DB testing, a sonic velocity meter was used to measure the $100-\mathrm{kHz}$ compression wave velocity $V_{\mathrm{p}}$ and shear wave velocity $V_{\mathrm{s}}$ in each sample. The objective of making the $V_{\mathrm{p}}$ and $V_{\mathrm{s}}$ wave determinations was to see if a correlation existed between $\sigma_{\mathrm{c}}$ and the velocity values. With the $V_{\mathrm{s}}$ and $V_{\mathrm{p}}$ measurements and the previously determined ice density (specific gravity $\gamma$ ), the parameters shown in the following flow chart were calculated:

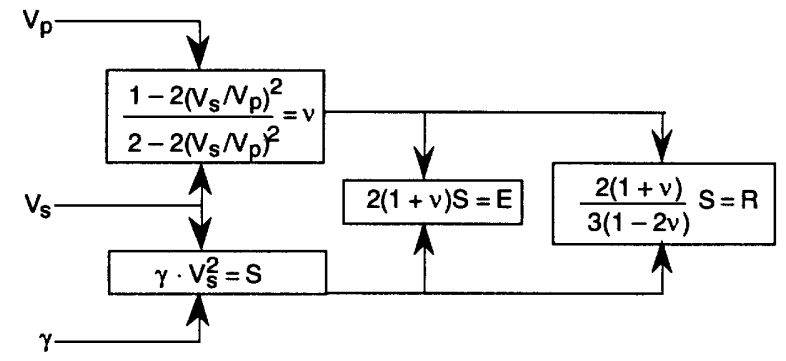

where $v=$ Poisson's ratio

$S=$ shear modulus

$E=$ Young's modulus

$R$ = volume rigidity.

The average dynamic Young's and shear moduli given in Table 1 for the axial DB tested ice were

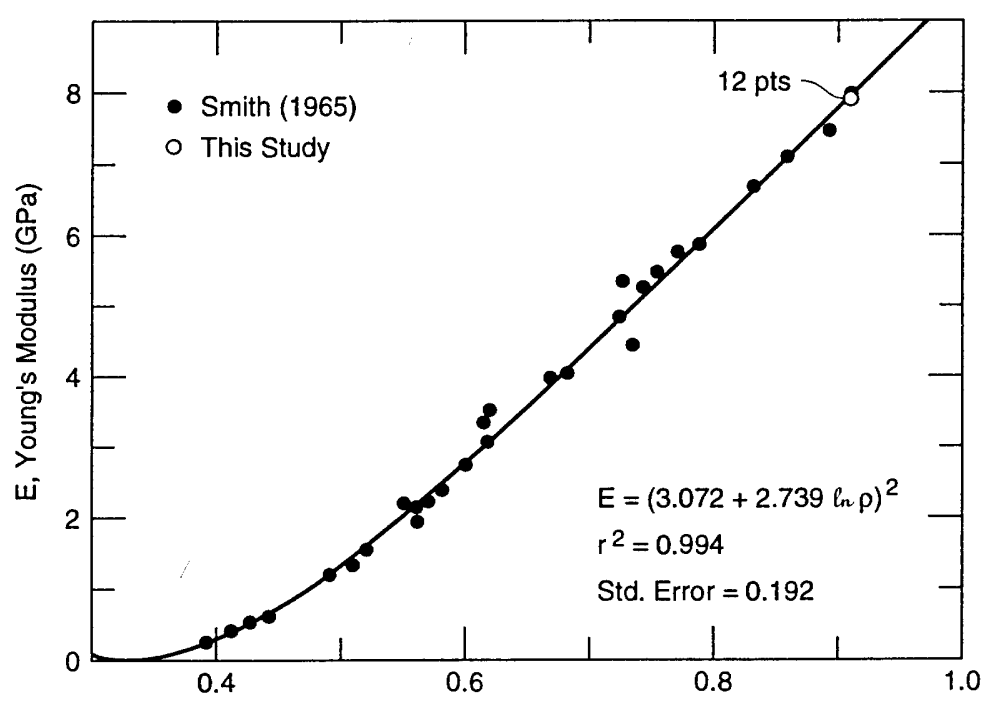

a. Young's modulus vs. density.

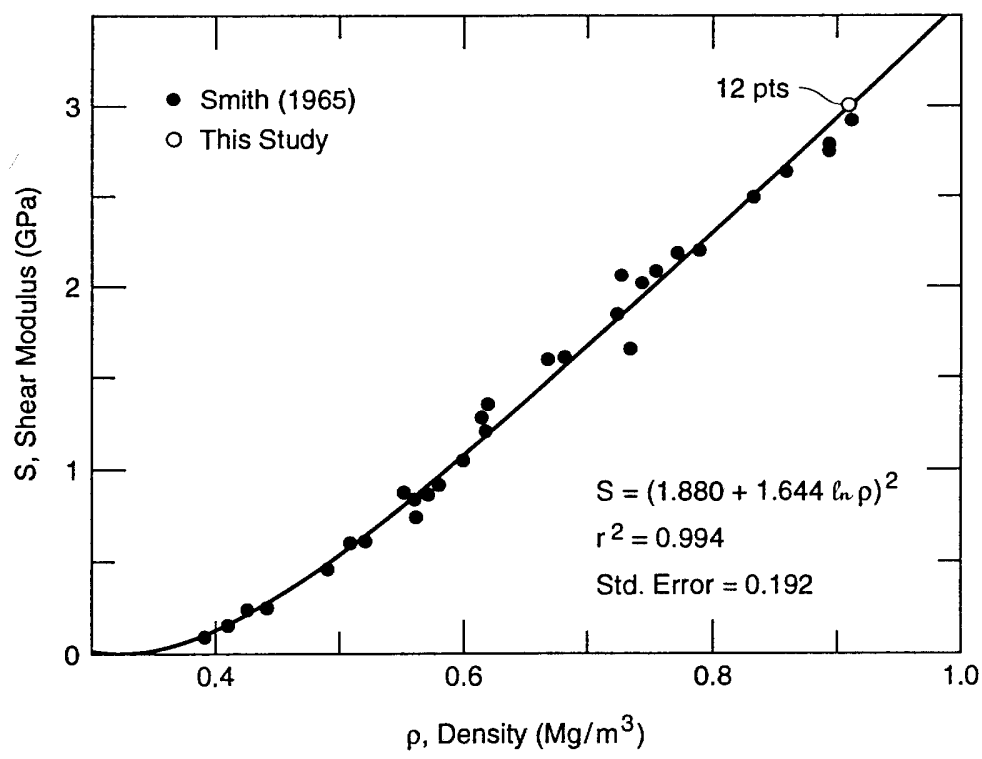

b. Shear modulus vs. density.

Figure 11. Dynamic modulus test results for polar firn and ice (Smith 1965) and the average test data from this study. 
Table 2. Axial double-point unconfined compressive strength vs. density of freshwater ice with a grain size of $3.5 \mathrm{~mm}$.

\begin{tabular}{|c|c|c|c|c|c|}
\hline \multicolumn{3}{|c|}{$-10^{\circ} \mathrm{C}$ tests } & \multicolumn{3}{|c|}{$-20^{\circ} \mathrm{C}$ tests } \\
\hline $\begin{array}{c}\text { Sample } \\
\text { no. }\end{array}$ & $\begin{array}{c}\text { Density } \\
\left(\mathrm{Mg} / \mathrm{m}^{3}\right)\end{array}$ & $\begin{array}{c}\sigma_{c} \\
(M P a)\end{array}$ & $\begin{array}{c}\text { Sample } \\
\text { no. }\end{array}$ & $\begin{array}{c}\text { Density } \\
\left(\mathrm{Mg} / \mathrm{m}^{3}\right)\end{array}$ & $\begin{array}{c}\sigma_{c} \\
(M P a)\end{array}$ \\
\hline $1 \mathrm{~A}$ & 0.909 & 7.40 & $1 \mathrm{~B}$ & 0.912 & 10.78 \\
\hline $2 \mathrm{~A}$ & 0.907 & 7.71 & 2B & 0.907 & 7.69 \\
\hline $3 \mathrm{~A}$ & 0.891 & 7.57 & 3B & 0.890 & 8.37 \\
\hline $4 \mathrm{~A}$ & 0.906 & 7.47 & 4B & 0.908 & 8.46 \\
\hline $5 \mathrm{~A}$ & 0.905 & 7.82 & $5 B$ & 0.907 & 7.84 \\
\hline $6 \mathrm{~A}$ & 0.902 & 7.72 & $6 \mathrm{~B}$ & 0.909 & 7.20 \\
\hline $7 \mathrm{~A}$ & 0.903 & 7.41 & 7B & 0.907 & 7.84 \\
\hline $8 \mathrm{~A}$ & 0.904 & 7.43 & $8 B$ & 0.909 & 8.92 \\
\hline $9 \mathrm{~A}$ & 0.907 & 6.95 & 9B & 0.906 & 8.97 \\
\hline $10 \mathrm{~A}$ & 0.898 & 7.99 & $10 \mathrm{~B}$ & 0.897 & 7.58 \\
\hline
\end{tabular}

\begin{tabular}{ccccccc}
\multicolumn{3}{c}{$-10^{\circ} \mathrm{C}$ tests } & & \multicolumn{3}{c}{$-20^{\circ} \mathrm{C}$ tests } \\
\cline { 1 - 2 } $\begin{array}{c}\text { Sample } \\
\text { no. }\end{array}$ & $\begin{array}{c}\text { Density } \\
\left(\mathrm{Mg} / \mathrm{m}^{3}\right)\end{array}$ & $\begin{array}{c}\sigma_{c} \\
(\mathrm{MPa})\end{array}$ & $\begin{array}{c}\text { Sample } \\
\text { no. }\end{array}$ & $\begin{array}{c}\text { Density } \\
\left(\mathrm{Mg} / \mathrm{m}^{3}\right)\end{array}$ & $\begin{array}{c}\sigma_{c} \\
(\mathrm{MPa})\end{array}$ \\
\hline 11A & 0.906 & 9.23 & & $11 \mathrm{~B}$ & 0.905 & 7.51 \\
$12 \mathrm{~A}$ & 0.905 & 8.47 & & $12 \mathrm{~B}$ & 0.904 & 8.79 \\
$13 \mathrm{~A}$ & 0.904 & 7.23 & & $13 \mathrm{~B}$ & 0.907 & 9.19 \\
$14 \mathrm{~A}$ & 0.893 & 8.05 & & $14 \mathrm{~B}$ & 0.875 & 7.45 \\
$15 \mathrm{~A}$ & 0.908 & 6.99 & & $15 \mathrm{~B}$ & 0.909 & 9.02 \\
$16 \mathrm{~A}$ & 0.904 & 7.64 & & $16 \mathrm{~B}$ & 0.905 & 7.36 \\
$17 \mathrm{~A}$ & 0.908 & 8.63 & & $17 \mathrm{~B}$ & 0.908 & 10.47 \\
$18 \mathrm{~A}$ & 0.896 & 8.00 & & $18 \mathrm{~B}$ & 0.898 & 9.48 \\
$19 \mathrm{~A}$ & 0.886 & 7.73 & & $19 \mathrm{~B}$ & 0.887 & 7.42 \\
Avg & 0.902 & 7.76 & Avg & 0.903 & 8.44 \\
\hline
\end{tabular}

Figure 12. Freshwater ice unconfined compressive strength vs. grain size at $-10^{\circ} \mathrm{C}$ and a strain rate of $10^{-3} \mathrm{~s}^{-1}$.

7.9 and $2.9 \mathrm{GPa}$, respectively. These average values compare extremely well with the dynamic modulus test results of Smith (1965), who tested firn and ice at Camp Century, Greenland, between $-12^{\circ}$ and $-15^{\circ} \mathrm{C}$ (Fig. 11). Also, the average value for Poisson's ratio in Table 1 agrees with the findings of Smith. No temperature correction was applied to the modulus data, as Mellor (1983) has emphasized that the modulus of ice is not sensitive to temperature in the range of these tests. No correlation was found between $\sigma_{\mathrm{c}}$ and the $V_{\mathrm{p}}$ and $V_{\mathrm{s}}$ wave determinations made on the ice, which had a specific gravity of $\sim 0.91$.

The axial $\mathrm{DB}$ test results made at $-10^{\circ}$ and $-20^{\circ} \mathrm{C}$ on the 3.5-mm-grain-size freshwater ice made at CRREL are listed in Table 2 . The average $\sigma_{\mathrm{c}}$ values at $-10^{\circ}$ and $-20^{\circ} \mathrm{C}$ were 7.76 and $8.44 \mathrm{MPa}$, respectively. The change in ice strength from $-10^{\circ}$ to $-20^{\circ} \mathrm{C}$ is $0.068 \mathrm{MPa} /{ }^{\circ} \mathrm{C}$, which is in agreement with the $\sigma_{\mathrm{c}}$ temperature correction previously discussed.

To assess how well the temperature-corrected axial $\mathrm{DB} \sigma_{\mathrm{c}}$ values agree with uniaxial unconfined compressive strength tests made at $10^{-3} \mathrm{~s}^{-1}$, the axial $D B \sigma_{\mathrm{c}}$ data are compared with $-10^{\circ} \mathrm{C}$ uniaxial $\sigma_{\mathrm{c}}$ data for ice of the same grain size. In Figure 12 the uniaxial $\sigma_{\mathrm{c}}$ test results of the authors listed and the average axial $\mathrm{DB} \sigma_{\mathrm{c}}$ values obtained for the ice with 3.5- and 5-mm grain sizes are shown. The axial $D B$ values fall nicely beside the appropriately weighted regression curve passing through the data. The outlier at the far right was not included in the regression analysis.

The data point shown as Camp Century in Figure 12 was determined as follows. In 1966 Gow (1975) determined the grain size of the firn and ice in the inclined drift at Camp Century, Greenland. This sloping passageway (Fig. 13) extended to a depth of $100 \mathrm{~m}$ below the surface, where the ice density reached a density of $0.89 \mathrm{Mg} / \mathrm{m}^{3}$ at an ambient temperature of $-24^{\circ} \mathrm{C}$. We obtained his data* and analyzed it as shown in Figure 14 . When the regression curve in Figure 14 is extrapolated to

* Personal communication, Dr. Anthony Gow, CRREL. 

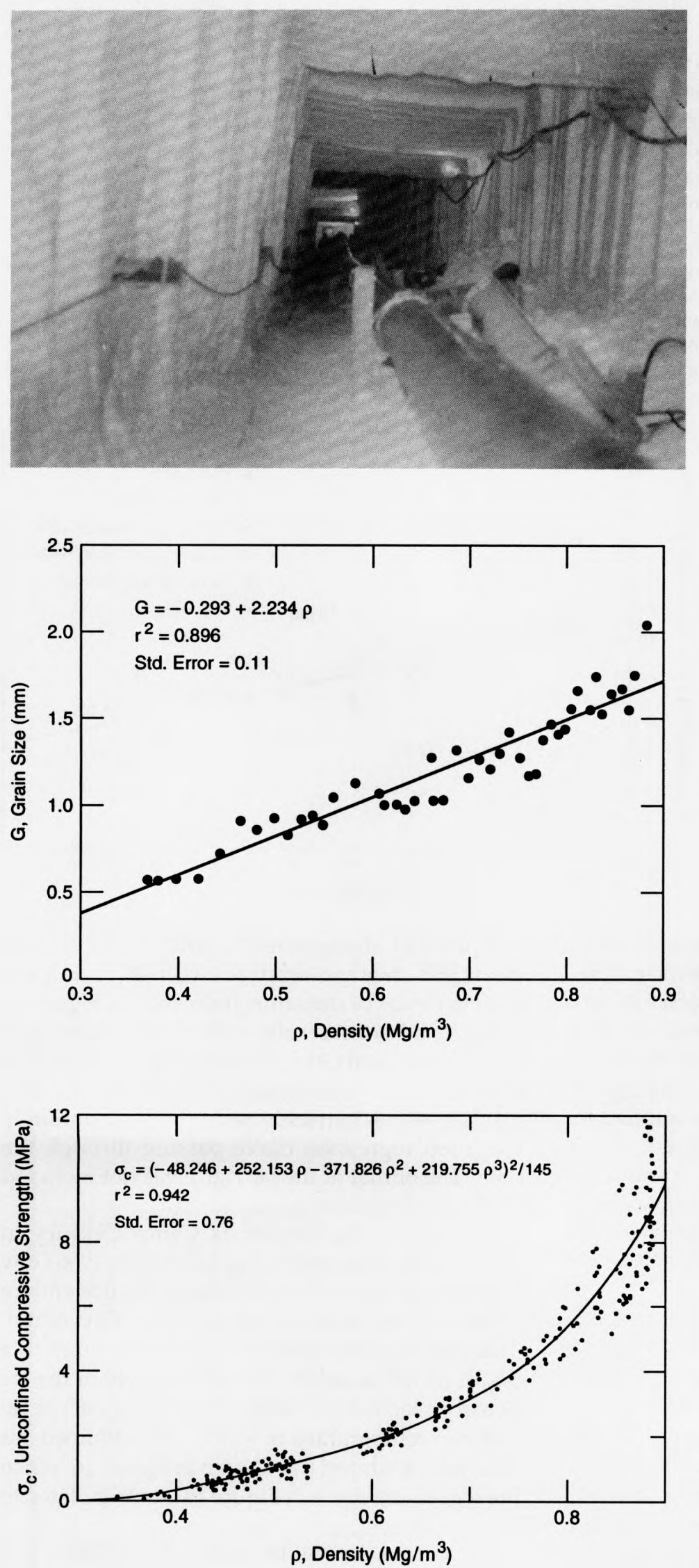

Figure 13. 1966 view looking down the inclined drift at Camp Century, Greenland, wherehomogenous ice sampleswere obtained. The pipeand metal objects beside the pipe were part of two conveyor systems used to remove material during mining of the drift.

Figure 14. Camp Century, Greenland, firn and ice grain size vs. density. (Data from Gow, private communication.)

Figure 15. Camp Century, Greenland, firn and ice unconfined compression strength vs. density at $-25^{\circ} \mathrm{C}$ and a strain rate of $\sim 10^{-3} \mathrm{~s}^{-1}$. (From Kovacs et al. 1969.) 
$0.92 \mathrm{Mg} / \mathrm{m}^{3}$, the density of pure ice at $-24^{\circ} \mathrm{C}$, we obtain a grain size of $1.76 \mathrm{~mm}$.

In 1967, uniaxial unconfined compression tests were made in the Camp Century inclined drift (Kovacs et al. 1969). These tests were made at a strain rate of about $10^{-3} \mathrm{~s}^{-1}$ and a temperature of $-25^{\circ} \mathrm{C}$. These test data are replotted in Figure 15. The regression curve passing through the test results, when extrapolated to a density of $0.92 \mathrm{Mg}$ / $\mathrm{m}^{3}$, gives a uniaxial unconfined compressive strength of $11.11 \mathrm{MPa}$. Using the $\sigma_{\mathrm{c}}$ temperature correction of $0.075 \mathrm{MPa} /{ }^{\circ} \mathrm{C}$, this uniaxial $\sigma_{\mathrm{c}}$ value reduces to $9.99 \mathrm{MPa}$ at $-10^{\circ} \mathrm{C}$, where the ice on warming would now have a density of $\sim 0.917$ $\mathrm{Mg} / \mathrm{m}^{3}$. This uniaxial $\sigma_{\mathrm{c}}$ value is plotted vs. the above-determined grain size of $1.76 \mathrm{~mm}$ in Figure 12.

There is considerable data scatter in Figure 15. However, such scatter is common with uniaxial unconfined compression tests. There are numerous reasons for this scatter, including sample preparation anomalies, internal flaws, type of icemachine contact, variations in sample alignment within the testing machine as well as ice density (i.e., porosity) variation. Gow (1975) pointed out that bubbles represent defects in the ice that "could be expected to influence the strength of the ice until they are entirely eliminated" as they act as stress concentrators that could lead to a lower peak strength. In any event, what Figure 15 does indicate is the need to run multiple tests on the same ice in order to obtain a representative mean peak strength value. In our previous work we attempted to use 10 or more samples to obtain an average value (Kovacs et al. 1969, 1977, Kovacs 1985). This minimum number is in agreement with the work of Yamaguchi (1970), who determined that a minimum of 10 samples are needed, and more recently by Kirk (1989), who indicated that 12 samples is a reasonable test number. This many samples can be difficult to obtain and transport to the testing facility. The ice at Camp Century was unique in that at a given depth one could extract endless samples of the same density and grain structure. Unfortunately this resource is no longer accessible. In principle, laboratory-grown ice can also be replicated to a high degree of structural and density conformity. However, first-year sea ice does not lend itself to repetitive sample conformity due to a wide variation in this material's composition and structure within the ice sheet (Weeks and Ackley 1982).

\section{Multiyear sea ice}

The physical and mechanical properties of the multiyear sea ice tested are listed in Table 3. Also shown is the time to failure and the total distance that the two load balls penetrated the ice at peak loading. The time to failure in the axial DB test is more than an order of magnitude shorter than the typical times to failure in a standard uniaxial unconfined compression test run at a $10^{-3} \mathrm{~s}^{-1}$ strain rate.

The axial DB $\sigma_{\mathrm{c}}$ values listed in Table 3 show considerable scatter. This is common with strength data obtained from uniaxial unconfined compression testing of multiyear sea ice. To illustrate this and compare our results with the uniaxial $\sigma_{\mathrm{c}}$ values obtained by Cox et al. (1984) at $-10^{\circ} \mathrm{C}$ on a universal electrohydraulic testing machine, we first applied the temperature correction of 0.075 $\mathrm{MPa} /{ }^{\circ} \mathrm{C}$ to the axial DB $\sigma_{\mathrm{c}}$ data obtained at $-5^{\circ} \mathrm{C}$. Both data sets are shown in Figure 16. The axial DB $\sigma_{c}$ test results fall well within those obtained by

Table 3. Test data for multiyear sea ice at $-5^{\circ} \mathrm{C}$.

\begin{tabular}{crrrcccccc}
$\begin{array}{c}\text { Sample } \\
\text { no. }\end{array}$ & $\begin{array}{c}\text { Brine } \\
\text { vol. } \\
(\%)\end{array}$ & $\begin{array}{c}\text { Air } \\
\text { vol. } \\
(\%)\end{array}$ & $\begin{array}{c}\text { Porosity } \\
(\%)\end{array}$ & $\begin{array}{c}\text { Bulk } \\
\text { density } \\
\left(\mathrm{Mg} / \mathrm{m}^{3}\right)\end{array}$ & $\begin{array}{c}\text { Ice } \\
\text { density } \\
\left(\mathrm{Mg} / \mathrm{m}^{3}\right)\end{array}$ & $\begin{array}{c}\text { Failure } \\
\text { load } \\
(\mathrm{kg})\end{array}$ & $\begin{array}{c}\text { Time } \\
\text { to failure } \\
(\mathrm{ms})\end{array}$ & $\begin{array}{c}\text { Ball } \\
\text { travel } \\
(\mathrm{mm})\end{array}$ & $\begin{array}{c}\sigma_{c} \\
(\mathrm{MPa})\end{array}$ \\
\hline R1A-a & 32.5 & 9.4 & 41.9 & 0.913 & 0.888 & 254 & 96 & 7.1 & 7.21 \\
R1A-b & 32.5 & 9.4 & 41.9 & 0.908 & 0.887 & 211 & 91 & 6.0 & 5.09 \\
R1D & 4.8 & 21.2 & 26.0 & 0.899 & 0.894 & 182 & 80 & 2.5 & 6.05 \\
C8-a & 15.7 & 8.8 & 24.5 & 0.912 & 0.895 & 200 & 50 & 2.8 & 5.59 \\
C8-b & 15.7 & 7.7 & 23.4 & 0.913 & 0.896 & 225 & 35 & 3.4 & 6.19 \\
C9-a & 9.7 & 15.4 & 25.2 & 0.905 & 0.895 & 202 & 40 & 6.9 & 5.74 \\
C9-b & 19.6 & 13.8 & 33.4 & 0.908 & 0.887 & 209 & 90 & 5.9 & 5.77 \\
C9-c & 16.7 & 6.8 & 23.5 & 0.914 & 0.896 & 216 & 40 & 5.4 & 5.96 \\
C11-a & 9.8 & 12.2 & 22.0 & 0.908 & 0.898 & 211 & 72 & 3.7 & 6.00 \\
C11-b & 12.7 & 10.5 & 23.2 & 0.910 & 0.896 & 257 & 42 & 3.2 & 7.11 \\
C11-c & 12.7 & 10.5 & 23.2 & 0.910 & 0.896 & 209 & 25 & 4.1 & 5.89 \\
C11-d & 17.7 & 8.0 & 25.7 & 0.913 & 0.894 & 254 & 110 & - & 6.99 \\
C11-e & 17.7 & 9.1 & 26.8 & 0.912 & 0.893 & 204 & 52 & 3.6 & 5.11 \\
Avg & 16.8 & 11.0 & 27.8 & 0.910 & 0.893 & 218 & 63 & 4.6 & 6.05 \\
\hline
\end{tabular}




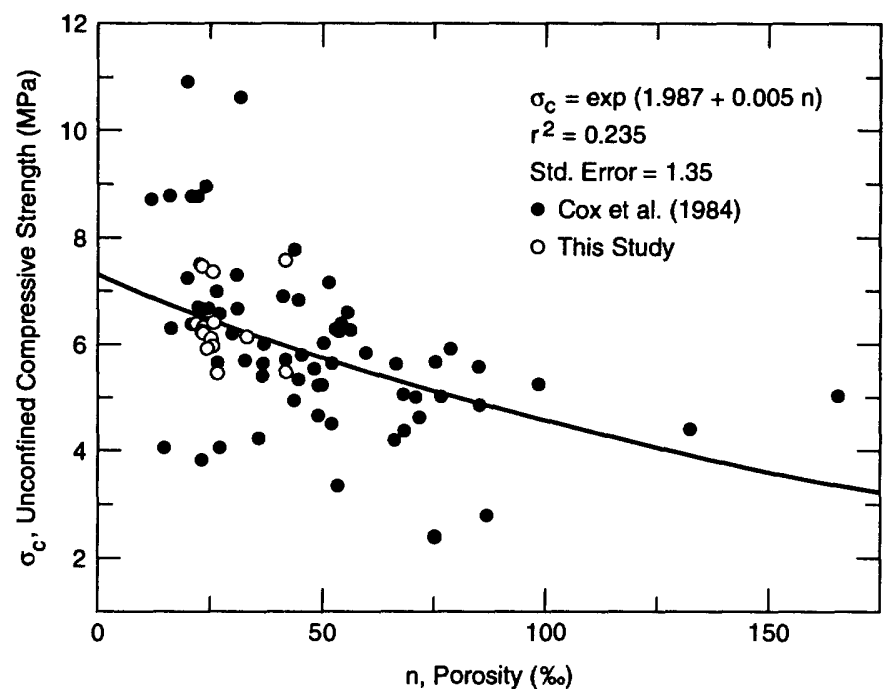

Figure 16. Multiyear sea ice unconfined compressive strength $v$ s. porosity at $-10^{\circ} \mathrm{C}$ and a strain rate of $10^{-3} \mathrm{~s}^{-1}$.
Cox et al. (1984). However, unlike their tests the axial DB test does not give stress-strain data from which an estimate of Young's modulus or Poisson's ratio can be made.

The regression curve passing through the data in Figure 16 indicates that the strength of multiyear sea ice, as with all materials, is governed by its porosity. However, many more test results are required to better define this trend, not only at this strain rate but at other strain rates and temperatures as well.

\section{First-year sea ice}

The strength of first-year sea ice is more difficult to categorize because of its wide structure anisotropy and inhomogeneity. Brine volume, ice density and porosity are the most-used sea ice physical properties against which sea ice strength has been correlated. The latter is preferred because porosity controls the strength of a material when all other conditions are equal.

Vertical and horizontal axial DB load tests were made on the sea ice from Steffanson Sound. As previously mentioned, this ice contained ice crystals about $11 \mathrm{~mm}$ in width. The c-axes were highly aligned in the horizontal plane. Tests were made at $-5^{\circ}$ and $-16^{\circ} \mathrm{C}$, as shown in Tables 4-6. Little has been published on sea ice strength vs. temperature and what has is conflicting (e.g. Schwarz [1971] showed a high $\sigma_{c}$ change with temperature, while Brown and McKittrich [1992] show the opposite). Therefore, the $\sigma_{c}$ data are referenced to the ice porosity, a common procedure in sea ice strength studies.

Axial DB load tests were applied perpendicular to the predominant c-axis orientation, or in the convention of Peyton (1966), at $90^{\circ}-90^{\circ}$, and parallel to the preferred c-axis alignment at $90^{\circ}-0^{\circ}$. The direction of the applied load was a visual estimate. Richter-Menge (1991) found that such visual estimates may be off by $\pm 5^{\circ}$. This error was found after her field samples were sent to the laboratory for thin-section analysis. The axial $\mathrm{DB} \sigma_{\mathrm{c}}$ values vs. porosity for the $90^{\circ}-0^{\circ}$ and $90^{\circ}-90^{\circ}$ axial DB load tests are shown in Figure 17. Also shown for comparison is the curve derived from the equation proposed by Timco and Frederking (1990) for estimating the average $\sigma_{\mathrm{c}}$ strength of horizontally

Table 4. Test data for first-year sea ice loaded perpendicular to the c-axes at $-16^{\circ} \mathrm{C}$.

\begin{tabular}{cccccccc}
$\begin{array}{c}\text { Sample } \\
\text { no. }\end{array}$ & $\begin{array}{c}\text { Bulk } \\
\text { density } \\
\left(\mathrm{Mg} / \mathrm{m}^{3}\right)\end{array}$ & $\begin{array}{c}\text { Melt } \\
\text { salinity } \\
(\%)\end{array}$ & $\begin{array}{c}\text { Brine } \\
\text { vol. } \\
(\%)\end{array}$ & $\begin{array}{c}\text { Air } \\
\text { vol. } \\
(\%)\end{array}$ & $\begin{array}{c}\text { Porosity } \\
(\%)\end{array}$ & $\begin{array}{c}\text { Ice } \\
\left(\mathrm{Mg} / \mathrm{m}^{3}\right)\end{array}$ & $\begin{array}{c}\sigma_{c} \\
(\mathrm{MPa})\end{array}$ \\
\hline 1 & 0.864 & 3.06 & 11.3 & 62.7 & 73.9 & 0.851 & 5.12 \\
2 & 0.889 & 2.92 & 11.1 & 35.4 & 46.5 & 0.877 & 6.47 \\
3 & 0.885 & 3.40 & 12.8 & 40.3 & 53.2 & 0.870 & 6.40 \\
4 & 0.897 & 3.41 & 13.0 & 27.8 & 40.8 & 0.882 & 5.73 \\
5 & 0.892 & 3.23 & 12.3 & 32.9 & 45.1 & 0.878 & 6.83 \\
6 & 0.894 & 2.65 & 10.1 & 30.3 & 40.4 & 0.882 & 5.72 \\
7 & 0.891 & 3.54 & 13.4 & 34.5 & 48.0 & 0.875 & 6.51 \\
8 & 0.890 & 2.94 & 11.2 & 34.3 & 45.5 & 0.877 & 6.49 \\
9 & 0.864 & 3.38 & 12.4 & 63.6 & 76.0 & 0.849 & 4.62 \\
10 & 0.896 & 3.35 & 12.8 & 28.9 & 41.7 & 0.881 & 6.11 \\
11 & 0.887 & 3.34 & 12.6 & 38.0 & 50.6 & 0.873 & 6.10 \\
12 & 0.896 & 2.73 & 10.4 & 27.7 & 38.1 & 0.884 & 6.55 \\
13 & 0.885 & 2.83 & 10.7 & 39.7 & 50.3 & 0.873 & 6.57 \\
14 & 0.888 & 3.33 & 12.6 & 37.4 & 50.0 & 0.873 & 5.57 \\
15 & 0.894 & 3.14 & 12.0 & 30.4 & 42.4 & 0.880 & 6.44 \\
16 & 0.899 & 3.11 & 11.9 & 25.0 & 36.9 & 0.885 & 5.90 \\
17 & 0.886 & 3.48 & 13.1 & 39.2 & 52.4 & 0.871 & 5.12 \\
18 & 0.885 & 3.01 & 11.4 & 39.9 & 51.2 & 0.872 & 5.49 \\
19 & 0.884 & 3.02 & 11.4 & 41.8 & 53.1 & 0.870 & 6.55 \\
20 & 0.896 & 3.12 & 11.9 & 29.0 & 40.9 & 0.882 & 5.92 \\
21 & 0.898 & 2.92 & 11.2 & 25.9 & 37.0 & 0.885 & 6.51 \\
Avg & 0.889 & 3.14 & 11.9 & 36.4 & 48.3 & 0.875 & 6.03 \\
\hline
\end{tabular}


Table 5. Test data for first-year sea ice loaded parallel to the c-axes.

\begin{tabular}{|c|c|c|c|c|c|c|c|}
\hline $\begin{array}{c}\text { Sample } \\
\text { no. }\end{array}$ & $\begin{array}{c}\text { Bulk } \\
\text { density } \\
\left(\mathrm{Mg} / \mathrm{m}^{3}\right)\end{array}$ & $\begin{array}{c}\text { Melt } \\
\text { salinity } \\
(\% o)\end{array}$ & $\begin{array}{l}\text { Brine } \\
\text { vol. } \\
(\% o)\end{array}$ & $\begin{array}{l}\text { Air } \\
\text { vol. } \\
(\% o)\end{array}$ & $\begin{array}{c}\text { Porosity } \\
(\% o)\end{array}$ & $\begin{array}{c}\text { Ice } \\
\text { density } \\
\left(\mathrm{Mg} / \mathrm{m}^{3}\right)\end{array}$ & $\begin{array}{c}\sigma_{c} \\
(M P a) \\
\end{array}$ \\
\hline \multicolumn{8}{|c|}{$-5^{\circ} \mathrm{C}$ tests } \\
\hline 1 & 0.908 & 3.21 & 31.4 & 15.2 & 46.7 & 0.875 & 5.78 \\
\hline 2 & 0.893 & 3.00 & 28.8 & 31.9 & 60.8 & 0.862 & 6.43 \\
\hline 3 & 0.893 & 3.04 & 29.2 & 32.0 & 61.2 & 0.862 & 6.06 \\
\hline 4 & 0.900 & 3.35 & 32.5 & 24.3 & 56.8 & 0.866 & 6.04 \\
\hline 5 & 0.903 & 3.36 & 32.7 & 31.4 & 64.1 & 0.868 & 4.49 \\
\hline 6 & 0.907 & 3.30 & 32.2 & 17.5 & 49.7 & 0.872 & 6.80 \\
\hline 7 & 0.908 & 3.72 & 36.4 & 16.9 & 53.2 & 0.869 & 6.14 \\
\hline 8 & 0.903 & 3.18 & 30.9 & 21.3 & 52.2 & 0.870 & 6.02 \\
\hline 9 & 0.901 & 3.48 & 33.8 & 33.9 & 67.7 & 0.865 & 4.53 \\
\hline 10 & 0.903 & 3.27 & 31.8 & 30.8 & 62.6 & 0.869 & 4.36 \\
\hline 11 & 0.900 & 3.30 & 32.0 & 24.3 & 56.3 & 0.866 & 5.58 \\
\hline Avg & 0.902 & 3.29 & 32.0 & 25.4 & 57.4 & 0.868 & 5.66 \\
\hline \multicolumn{8}{|c|}{$-16^{\circ} \mathrm{C}$ tests } \\
\hline 1 & 0.893 & 3.50 & 13.3 & 32.2 & 45.6 & 0.877 & 5.94 \\
\hline 2 & 0.898 & 3.70 & 14.2 & 26.7 & 40.9 & 0.882 & 6.51 \\
\hline 3 & 0.893 & 3.63 & 13.8 & 32.7 & 46.5 & 0.877 & 6.97 \\
\hline 4 & 0.884 & 3.33 & 12.5 & 42.1 & 54.6 & 0.869 & 7.62 \\
\hline 5 & 0.891 & 3.18 & 12.1 & 33.7 & 45.8 & 0.877 & 6.75 \\
\hline 6 & 0.898 & 3.74 & 14.3 & 27.3 & 41.6 & 0.881 & 5.68 \\
\hline 7 & 0.888 & 3.46 & 13.1 & 37.6 & 50.7 & 0.873 & 6.40 \\
\hline 8 & 0.890 & 3.41 & 12.9 & 35.5 & 48.5 & 0.875 & 7.66 \\
\hline 9 & 0.897 & 3.63 & 13.9 & 27.5 & 41.4 & 0.881 & 6.92 \\
\hline 10 & 0.891 & 3.39 & 12.9 & 33.9 & 46.8 & 0.876 & 6.72 \\
\hline 11 & 0.890 & 3.61 & 13.7 & 35.8 & 49.4 & 0.874 & 5.07 \\
\hline 12 & 0.897 & 3.08 & 11.8 & 27.1 & 38.9 & 0.883 & 7.25 \\
\hline Avg & 0.892 & 3.47 & 13.2 & 32.7 & 45.9 & 0.877 & 6.63 \\
\hline
\end{tabular}

loaded columnar sea ice. Their equation for this curve is

$$
\sigma_{\mathrm{c}}=37(\dot{\varepsilon})^{0.22}\left[1-(n / 270)^{0.5}\right]
$$

where $n$ is porosity. This may be simplified to

$$
\sigma_{\mathrm{c}}=8.08-0.492(n)^{0.5}
$$

for a strain rate $\dot{\varepsilon}$ of $10^{-3} \mathrm{~s}^{-1}$. Their universal equation relates the horizontally loaded uniaxial unconfined compressive strength explicitly to columnar sea ice, porosity and strain rate, and implicitly to the salinity, temperature and brine-free density of the sea ice (Timco and Frederking 1991). As seen in these figures, the axial $\mathrm{DB} \sigma_{\mathrm{c}}$ vs. $n$ trend is similar to Timco and Frederking's, but the axial $\mathrm{DB} \sigma_{\mathrm{c}}$ values are higher. This may be due to the higher apparent strain rate under which our tests were made, a strain rate for which their equation may not be valid (Timco and Frederking 1991). The axial $\mathrm{DB} \sigma_{\mathrm{c}}$ results may also be compared with the first-year sea ice uniaxial $\sigma_{c}$ results of RichterMenge (1991), which were made at $-10^{\circ} \mathrm{C}$ and a strain rate of $10^{-3} \mathrm{~s}^{-1}$. At a load direction of $90^{\circ}-0^{\circ}$
Table 6. Test data for first-year sea ice with aligned c-

\begin{tabular}{|c|c|c|c|c|c|c|c|}
\hline $\begin{array}{c}\text { Sample } \\
\text { no. }\end{array}$ & $\begin{array}{c}\text { Bulk } \\
\text { density } \\
\left(\mathrm{Mg} / \mathrm{m}^{3}\right)\end{array}$ & $\begin{array}{c}\text { Melt } \\
\text { salinity } \\
(\% o)\end{array}$ & $\begin{array}{l}\text { Brine } \\
\text { vol. } \\
(\% o)\end{array}$ & $\begin{array}{l}\text { Air } \\
\text { vol. } \\
(\% o)\end{array}$ & $\begin{array}{c}\text { Porosity } \\
(\% o)\end{array}$ & $\begin{array}{c}\text { Ice } \\
\text { density } \\
\left(\mathrm{Mg} / \mathrm{m}^{3}\right)\end{array}$ & $\begin{array}{c}\sigma_{c} \\
(\stackrel{M P a}{M})\end{array}$ \\
\hline \multicolumn{8}{|c|}{$-5^{\circ} \mathrm{C}$ tests } \\
\hline 1 & 0.883 & 3.25 & 30.9 & 43.3 & 74.2 & 0.850 & 5.45 \\
\hline 2 & 0.873 & 3.10 & 29.1 & 53.3 & 82.5 & 0.842 & 5.47 \\
\hline 3 & 0.870 & 3.07 & 28.8 & 56.5 & 85.3 & 0.839 & 3.86 \\
\hline 4 & 0.886 & 3.65 & 34.8 & 40.4 & 75.2 & 0.849 & 4.32 \\
\hline 5 & 0.884 & 3.32 & 31.6 & 42.0 & 73.6 & 0.850 & 5.14 \\
\hline 6 & 0.887 & 3.45 & 32.9 & 39.2 & 72.2 & 0.851 & 4.01 \\
\hline 7 & 0.893 & 3.73 & 35.9 & 32.8 & 68.7 & 0.855 & 4.92 \\
\hline 8 & 0.885 & 3.94 & 37.6 & 41.4 & 78.9 & 0.845 & 5.62 \\
\hline 9 & 0.881 & 2.81 & 26.7 & 44.5 & 71.2 & 0.852 & 4.84 \\
\hline 10 & 0.885 & 3.04 & 29.0 & 40.5 & 69.5 & 0.854 & 3.97 \\
\hline 11 & 0.889 & 4.16 & 39.8 & 38.2 & 78.0 & 0.846 & 5.38 \\
\hline 12 & 0.871 & 3.09 & 29.0 & 55.3 & 84.3 & 0.840 & 5.21 \\
\hline 13 & 0.873 & 3.10 & 29.1 & 54.0 & 83.1 & 0.841 & 5.12 \\
\hline 14 & 0.864 & 3.76 & 35.0 & 64.5 & 99.4 & 0.826 & 3.91 \\
\hline 15 & 0.890 & 2.97 & 28.5 & 34.7 & 63.2 & 0.860 & 4.95 \\
\hline 16 & 0.889 & 3.44 & 32.9 & 36.6 & 69.5 & 0.854 & 4.29 \\
\hline Avg & 0.881 & 3.37 & 32.0 & 44.8 & 76.8 & 0.847 & 4.78 \\
\hline \multicolumn{8}{|c|}{$-7^{\circ} \mathrm{C}$ tests } \\
\hline 1 & 0.898 & 3.11 & 22.4 & 26.1 & 48.5 & 0.874 & 5.31 \\
\hline 2 & 0.901 & 2.87 & 20.7 & 22.9 & 43.6 & 0.878 & 4.24 \\
\hline 3 & 0.915 & 2.88 & 21.1 & 6.8 & 28.0 & 0.892 & 5.05 \\
\hline 4 & 0.914 & 3.75 & 27.5 & 9.9 & 37.4 & 0.884 & 5.91 \\
\hline 5 & 0.912 & 3.91 & 28.6 & 11.5 & 40.1 & 0.881 & 5.31 \\
\hline 6 & 0.879 & 4.29 & 30.2 & 47.7 & 78.0 & 0.846 & 4.89 \\
\hline 7 & 0.928 & 3.79 & 28.2 & 5.7 & 22.5 & 0.897 & 5.95 \\
\hline 8 & 0.902 & 3.66 & 26.5 & 22.1 & 48.6 & 0.873 & 5.05 \\
\hline 9 & 0.918 & 3.99 & 29.4 & 5.2 & 34.5 & 0.996 & 5.00 \\
\hline Avg & 0.907 & 3.58 & 26.1 & 17.5 & 42.4 & 0.891 & 5.19 \\
\hline \multicolumn{8}{|c|}{$-18^{\circ} \mathrm{C}$ tests } \\
\hline 1 & 0.920 & 3.28 & 12.3 & 2.9 & 15.2 & 0.905 & 5.25 \\
\hline 2 & 0.908 & 3.79 & 14.1 & 15.9 & 30.0 & 0.892 & 5.79 \\
\hline 3 & 0.908 & 3.41 & 12.6 & 15.9 & 28.5 & 0.893 & 6.28 \\
\hline 4 & 0.922 & 2.91 & 11.0 & 0.7 & 11.7 & 0.909 & 7.42 \\
\hline 5 & 0.917 & 2.91 & 10.9 & 6.0 & 16.9 & 0.904 & 7.14 \\
\hline 6 & 0.907 & 3.97 & 14.7 & 17.6 & 32.3 & 0.890 & 6.13 \\
\hline 7 & 0.874 & 4.69 & 16.7 & 53.8 & 70.5 & 0.855 & 5.50 \\
\hline 8 & 0.897 & 3.14 & 11.5 & 27.7 & 39.2 & 0.883 & 5.55 \\
\hline 9 & 0.907 & 4.06 & 15.0 & 18.1 & 33.1 & 0.889 & 5.75 \\
\hline Avg & 0.907 & 3.57 & 13.2 & 17.62 & 30.8 & 0.891 & 6.09 \\
\hline
\end{tabular}
axes, loaded vertically.

she reported an average $\sigma_{\mathrm{c}}$ of $7.30 \mathrm{MPa}$ for sea ice with an average porosity of $30.5 \%$. At this porosity the regression curve in Figure 17a gives a $\sigma_{c}$ value of $7.41 \mathrm{MPa}$. For her tests at a load direction of $90^{\circ}-90^{\circ}$, the average porosity and $\sigma_{\mathrm{c}}$ values were $33.0 \%$ and $6.56 \mathrm{MPa}$, respectively. This $\sigma_{\mathrm{c}}$ value compares with a value of $6.61 \mathrm{MPa}$, which can be determined for the same porosity from the regression curve in Figure 17b.

The regression curves were used to determine that the $\sigma_{\mathrm{c}}$ values for $90^{\circ}-0^{\circ}$ and $90^{\circ}-90^{\circ}$ were 6.81 and $6.32 \mathrm{MPa}$, respectively, at $n=40 \%$ (Fig. 17). These values and the uniaxial $\sigma_{c}$ values of RichterMenge (1991), at an unknown porosity, are plotted 

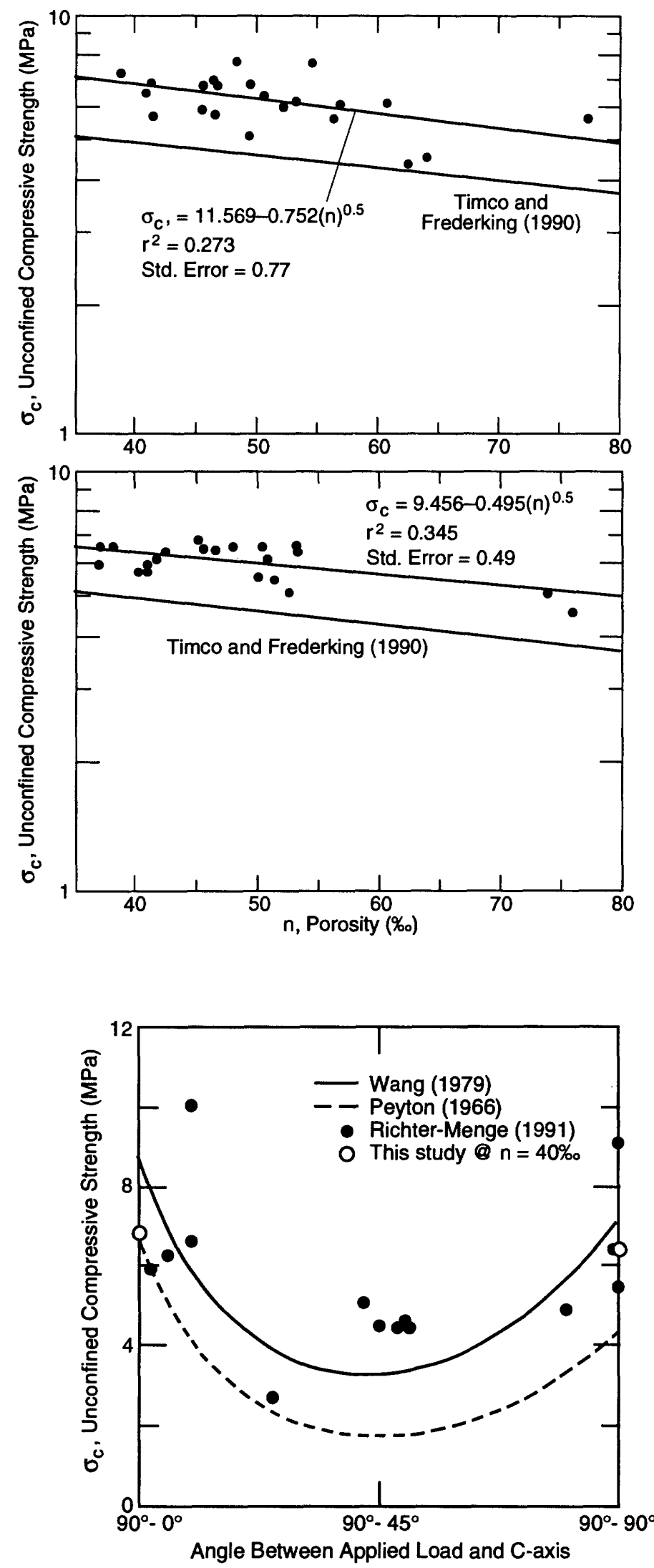

a. Loaded parallel to the predominant horizontal c-axis direction. b. Loaded perpendicular to the predominant horizontal c-axis direction.

Figure 17. Horizontal first-year sea ice unconfined compressive strength vs. porosityat a strain rate of $10^{-3} \mathrm{~s}^{-1}$.
Figure 18. Horizontal first-year sea ice unconfined compressive strength $v$ s. the angle between the applied load and the predominant c-axis direction. 
in Figure 18. Also shown is the horizontal $\sigma_{\mathrm{c}}$ trend vs. the angle between the applied load and the preferred c-axis direction as estimated by Wang (1979) from tests made at $-10^{\circ} \mathrm{C}$ and a strain rate of $10^{-3}$ $\mathrm{s}^{-1}$ and the trend established by Peyton (1966) from tests at a slower strain rate, which he gives in terms of a load rate of $\sim 0.053 \mathrm{MPa} / \mathrm{s}$. The temperature at which his tests were made was not given in his report.

The horizontal uniaxial $\sigma_{\mathrm{c}}$ anisotropy trend shown in Figure 18 is related to the sea ice structure and is similar to the strength anisotropy trends observed in the data from uniaxial $\sigma_{\mathrm{c}}$ tests madeon bedded rock (Brown et al. 1977). The trend established by Peyton (1966) was well determined through a large number of uniaxial $\sigma_{\mathrm{c}}$ tests. The curve proposed by Wang (1979) was less well determined experimentally. However, it can be inferred from the tests of Richter-Menge (1991), as plotted in Figure 18, and the data shown in Borodkin et al. (1992) that further testing is required to clarify the strength anisotropy trend indicated by the Wang and Peyton curves in Figure 18. The axial $\mathrm{DB} \sigma_{\mathrm{c}}$ values at $n=40 \%$, shown in Figure 18 , are comparable with the uniaxial $\sigma_{\mathrm{c}}$ values of Richter-Mengebut do not reveal the magnitude of the strength anisotropy suggested by the Wang curve. Sinha (1983) also observed little, if any, difference between the uniaxial $\sigma_{c}$ values from tests made parallel vs. perpendicular to the preferred c-axis direction. His tests were made at $-10^{\circ} \mathrm{C}$ and a strain rate of about $\sim 10^{-4} \mathrm{~s}^{-1}$.

Axial DB load tests were made on Stefanson Sound first-year sea ice with the load applied in the growth direction, parallel to the columnar crystal axes. Tests were made at $-5^{\circ},-7^{\circ}$ and $-18^{\circ} \mathrm{C}$ as listed in Table 6 . The average $\sigma_{\mathrm{c}}$ values at $-7^{\circ}$ and $-18^{\circ} \mathrm{C}$ were 5.19 and $6.09 \mathrm{MPa}$, respectively. The axial $\mathrm{DB} \sigma_{\mathrm{c}}$ difference represents a temperature effect of $0.082 \mathrm{MPa} /{ }^{\circ} \mathrm{C}$.

Another set of vertical axial $D B$ tests were made at $-7^{\circ}$ and $-17^{\circ} \mathrm{C}$ on first-year sea ice obtained from a melt pool in a multiyear floe (Table 7). In this sea ice the crystals had an average width of $10 \mathrm{~mm}$, and the c-axes did not have a preferred horizontal alignment. The difference in strength at each temperature indicates a $\sigma_{\mathrm{c}}$ variation of $0.07 \mathrm{MPa} /{ }^{\circ} \mathrm{C}$. Note that the porosity at $-7^{\circ} \mathrm{C}$ is about $66 \%$ more than the value at $-17^{\circ} \mathrm{C}$. This is related to the change in brine volume that occurs with temperature. When the temperature of the sea ice decreases, a portion of the water in the brine inclusions freezes to the chamber walls. This occurs in order to maintain the brine concentration in thermal equilibrium. When the ice warms, the reverse occurs; that is, brine dilution occurs as the enriched brine causes the chamber's freshwater ice walls to melt.

At $-7^{\circ}$ and $-18^{\circ} \mathrm{C}$ the average $\sigma_{\mathrm{c}}$ value for the caxis aligned Stefanson Sound sea ice was 5.19 and $6.09 \mathrm{MPa}$, respectively. For the non-aligned melt pond ice the average $\sigma_{\mathrm{c}}$ value was 5.21 and 5.91 $\mathrm{MPa}$ at $-7^{\circ}$ and $-17^{\circ} \mathrm{C}$, respectively. Because these values are in good agreement, it would appear that the vertical $\sigma_{\mathrm{c}}$ strength of columnar sea ice is not affected by horizontal c-axis alignment.

All the vertical axial $D B \sigma_{c}$ values are plotted vs. $n$ in Figure 19. At a porosity of $40 \%$ o the regression curve through the data gives a $\sigma_{\mathrm{c}}$ of $5.44 \mathrm{MPa}$. This value is low when compared to the horizontal axial DB load test results in Figure 17, and it is not in conformity with vertical vs. horizontal uniaxial unconfined compression tests made on first-year sea ice.

To illustrate the latter, Sinha (1983) reported vertical uniaxial $\sigma_{\mathrm{c}}$ values about $2-5$ times higher

Table 7. Test data for melt pond sea ice, with random crystal c-axis orientations, loaded vertically.

\begin{tabular}{|c|c|c|c|c|c|c|c|}
\hline $\begin{array}{c}\text { Sample } \\
\text { no. }\end{array}$ & $\begin{array}{c}\text { Bulk } \\
\text { density } \\
\left(\mathrm{Mg} / \mathrm{m}^{3}\right) \\
\end{array}$ & $\begin{array}{c}\text { Melt } \\
\text { salinity } \\
(\% o)\end{array}$ & $\begin{array}{c}\text { Brine } \\
\text { vol. } \\
(\%)\end{array}$ & $\begin{array}{l}\text { Air } \\
\text { vol. } \\
(\% o)\end{array}$ & $\begin{array}{c}\text { Porosity } \\
(\% o)\end{array}$ & $\begin{array}{c}\text { Ice } \\
\text { density } \\
\left(\mathrm{Mg} / \mathrm{m}^{3}\right) \\
\end{array}$ & $\begin{array}{c}\sigma_{c} \\
(M P a)\end{array}$ \\
\hline \multicolumn{8}{|c|}{$-7^{\circ} \mathrm{C}$ tests } \\
\hline 1 & 0.910 & 4.31 & 31.4 & 14.4 & 45.8 & 0.876 & 5.33 \\
\hline 2 & 0.908 & 4.50 & 32.7 & 17.2 & 49.9 & 0.872 & 5.22 \\
\hline 3 & 0.912 & 3.98 & 29.1 & 12.0 & 41.1 & 0.880 & 5.53 \\
\hline 4 & 0.910 & 4.88 & 35.6 & 15.7 & 51.2 & 0.871 & 5.92 \\
\hline 5 & 0.911 & 4.00 & 29.2 & 13.2 & 42.4 & 0.879 & 5.51 \\
\hline 6 & 0.909 & 4.12 & 30.0 & 15.3 & 45.3 & 0.876 & 4.26 \\
\hline 7 & 0.907 & 4.58 & 33.3 & 17.8 & 51.1 & 0.871 & 4.79 \\
\hline 8 & 0.909 & 4.27 & 31.1 & 15.9 & 47.1 & 0.875 & 5.48 \\
\hline 9 & 0.907 & 4.58 & 33.3 & 18.1 & 51.4 & 0.871 & 5.18 \\
\hline 10 & 0.894 & 3.68 & 26.4 & 31.4 & 57.7 & 0.865 & 5.53 \\
\hline 11 & 0.909 & 4.57 & 33.3 & 16.1 & 49.4 & 0.873 & 4.74 \\
\hline 12 & 0.911 & 4.02 & 29.4 & 13.2 & 42.6 & 0.879 & 4.94 \\
\hline 13 & 0.910 & 3.50 & 25.5 & 13.7 & 39.2 & 0.882 & 5.33 \\
\hline Avg & 0.908 & 4.23 & 30.8 & 16.5 & 47.2 & 0.875 & 5.21 \\
\hline \multicolumn{8}{|c|}{$-17^{\circ} \mathrm{C}$ tests } \\
\hline 1 & 0.910 & 4.19 & 15.6 & 15.1 & 30.6 & 0.891 & 5.47 \\
\hline 2 & 0.980 & 3.45 & 12.8 & 15.6 & 28.4 & 0.893 & 5.28 \\
\hline 3 & 0.914 & 4.04 & 15.1 & 9.7 & 24.8 & 0.897 & 7.65 \\
\hline 4 & 0.899 & 3.65 & 13.4 & 26.0 & 39.4 & 0.883 & 6.95 \\
\hline 5 & 0.915 & 5.09 & 19.0 & 9.7 & 28.8 & 0.893 & 5.64 \\
\hline 6 & 0.909 & 3.51 & 13.0 & 14.5 & 27.6 & 0.894 & 5.34 \\
\hline 7 & 0.908 & 3.62 & 13.4 & 15.7 & 29.1 & 0.893 & 5.78 \\
\hline 8 & 0.900 & 3.41 & 12.5 & 24.3 & 36.8 & 0.886 & 5.58 \\
\hline 9 & 0.902 & 3.89 & 14.3 & 22.9 & 37.2 & 0.885 & 5.95 \\
\hline 10 & 0.907 & 3.33 & 12.3 & 16.6 & 28.9 & 0.893 & 5.12 \\
\hline 11 & 0.911 & 3.99 & 14.9 & 13.0 & 27.9 & 0.894 & 6.17 \\
\hline 12 & 0.907 & 4.27 & 15.8 & 18.1 & 34.0 & 0.888 & 5.86 \\
\hline 13 & 0.910 & 4.31 & 16.0 & 14.4 & 30.4 & 0.891 & 6.01 \\
\hline Avg & 0.913 & 3.90 & 14.5 & 16.6 & 31.1 & 0.891 & 5.91 \\
\hline
\end{tabular}




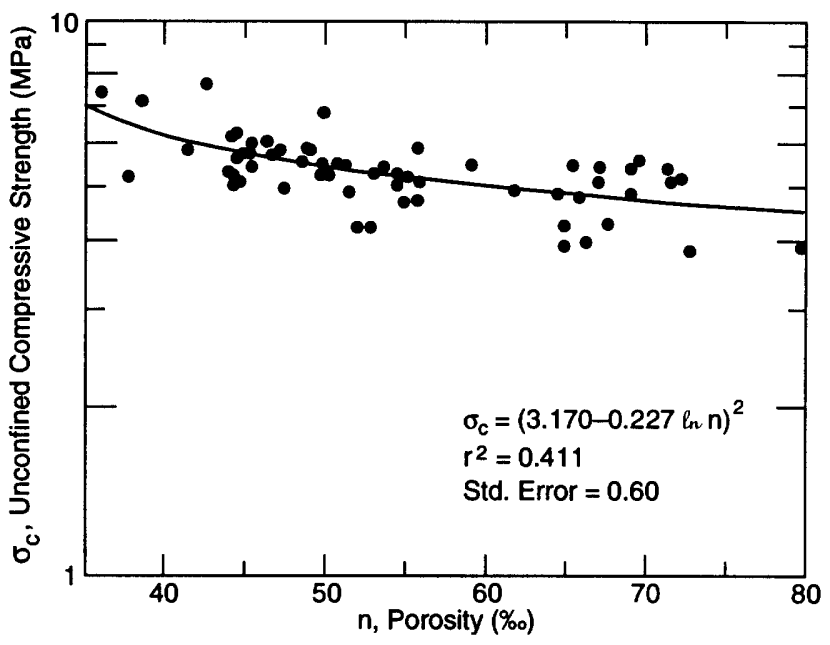

than those obtained from horizontal tests at $-10^{\circ} \mathrm{C}$ and a strain rate between about $4 \times 10^{-5}$ and $7 \times$ $10^{-5} \mathrm{~s}^{-1}$. Frederking and Timco (1989) observed a uniaxial $\sigma_{c}$ value three times larger in their vertical vs. horizontal load tests at $-11^{\circ} \mathrm{C}$ and at strain rates between $2 \times 10^{-5}$ and $5 \times 10^{-4} \mathrm{~s}^{-1}$. Kuehn and Schulson (1993) made uniaxial tests onlaboratory-grown columnar saline ice with unaligned c-axes in the horizontal plane. The only consistency shown over a temperature range of $-5^{\circ}$ to $-40^{\circ} \mathrm{C}$ and strain rates from $10^{-6}$ to $10^{-1} \mathrm{~s}^{-1}$ was that the vertically loaded ice failed at a stress 1.1-7.5 times higher than the horizontally loaded samples. At a strain rate of $10^{-3} \mathrm{~s}^{-1}$ and temperatures of $-5^{\circ},-10^{\circ},-20^{\circ}$ and $-40^{\circ} \mathrm{C}$, the vertically loaded samples were $1.2,2.8$, 1.1 and 2 times stronger, respectively, than the horizontally loaded samples. Richter-Menge(1986) showed first-year sea ice to be about 1.5 times stronger when loaded vertically to the crystal columns than when loaded horizontally. Her unconfined compression tests were made at $90^{\circ}$ to the mean c-axis direction at a test temperature of $-10^{\circ} \mathrm{C}$ and a strain rate of $10^{-3} \mathrm{~s}^{-1}$. However, Schwarz (1970) found that the uniaxial $\sigma_{\mathrm{c}}$ of Baltic Sea ice, tested at $0^{\circ},-10^{\circ}$ and $-20^{\circ} \mathrm{C}$ and at strain rates from $3 \times 10^{-4}$ to $3 \times 10^{-1} \mathrm{~s}^{-1}$, was always stronger when loaded in the horizontal vs. vertical direction!

Except for the contradictory results of Schwarz, there is a strong indication that sea ice fails at a higher uniaxial $\sigma_{\mathrm{c}}$ when the ice is loaded in the growth direction vs. parallel to it. However, it is not possible at this time to quantify what the verticalto-horizontal strength ratio is for a given set of sea ice properties and loading conditions. With regard to the anomalous axial DB vertical-vs.-horizontal load test results, it can be expected that ball loading parallel to the crystal columns will induce stresses that result in the ice splitting along its weakest
Figure 19. Vertical first-year sea ice unconfined compressive strength $v$ s. porosity at a strain rate of
$10^{-3} \mathrm{~s}^{-1}$.

plane, parallel to the crystal lattice basal plane and the columnar ice structure. Therefore, it is most reasonable that the axial $\mathrm{DB}$ test would give the results noted.

\section{DISCUSSION}

The axialDB test results presented in this report indicate that this test is well suited for determining the unconfined compressivestrength of multiyear sea iceand freshwater ice. The agreement between the axial DB and laboratory uniaxial unconfined compression tests made on these ice types was found to be excellent at a strain rate of $10^{-3} \mathrm{~s}^{-1}$.

The axial DB tests on first-year sea ice, a less "brittle" material, were more difficult to assess because of the inherent variation in sea ice structure and physical properties. Numerous strength tests on sea ice need to be made to establish trends related to crystal size, load orientation and rate vs. the ice structure, ice porosity, temperature, etc. The axial DB horizontal load test results did show a $\sigma_{c}$ dependence on the direction of the applied load relative to the c-axis alignment. The results also appear to give a good assessment of the mean horizontal sea ice strength, which is the preferred strength for usein the design of offshore structures (Wang 1979).

In this report a $\sigma_{\mathrm{c}}$ temperature correction factor of $0.075 \mathrm{MPa} /{ }^{\circ} \mathrm{C}$ was used to correct freshwater and multiyear sea ice test results to a common temperature. This value was reported to be in agreement with the results of other authors and was found to be in agreement with the test results reported here. However, this temperature correction is not in agreement with the test results of Carter (1970), Schwarz (1970), Haynes (1979) and Schulson (1990). These investigators found tem- 
perature correction factors for uniaxial unconfined compressive strength to be two to seven times higher than the one used in this report. Further work is needed to resolve this inconsistency, as well as the issue of sea ice strength vs. porosity and temperature. For example, a given sea ice porosity can be found at different temperatures. Therefore, all other conditions being equal, the ice strength will be temperature dependent. The strength equation of Timco and Frederking (1990) presented in this report does not account for this porosity-vs.temperature effect, which must be responsible for some of the scatter observed in the unconfined compression test results.

Another issue not addressed in this report is the effect of sample geometry and size and the various types of end conditions that may have affected the uniaxial $\sigma_{c}$ values obtained by other investigators. For example, "bonded end caps exert a lateral confinement which suppresses both crack nucleation and the propagation through the end zones of axial splits which initiate during loading" (Schulson 1990). This confinement results in failure strengths on the order of $20 \%$ higher than if the ends were not constrained. Such test confinement vs. non-confinement, as well as sample-machine alignment and different sample slenderness ratios, may have contributed to the variation in the uniaxial $\sigma_{\mathrm{c}}$ values reported in the literature and used for comparative purposes in this report.

The axial DB test will not provide $\sigma_{\mathrm{c}}$ values at a strain rate other than $10^{-3} \mathrm{~s}^{-1}$, nor will the test provide stress-strain information for determining, for example, Young's modulus. However, a simple sonic velocity meter, as used in this study, may well serve this purpose. In rock mechanics it has been shown that Young's modulus can be well correlated with the dynamic modulus derived from sonic velocity tests (Eissa and Kazi 1988). With additional testing of ice a similar correlation could be found.

In rock mechanics the point-load strength frequently replaces the uniaxial unconfined compressive strength because the test is quicker to perform and less-stringentsamplepreparations are required. The test may be readily done in the field at nearly in-situ conditions and has been shown to be as reliable as the uniaxial unconfined compression test, with its expensive electrohydraulic loading and sample preparation systems. Similar exacting sample preparation procedures and testing equipment are required in the uniaxial unconfined compression testing of ice. For axial DB tests the only equipment required is a simple loading jig, a handoperated hydraulic pump ram and a load cell with a digital peak-load indicator. Auxiliary equipment would include a cutoff saw, used to section core into lengths of $1.06 \pm 0.01$ times the core diameter, and appropriate measuring equipment for determining sample density and temperature. The findings of this report indicate that the axial DB test is ideally suited for determining the unconfined compressive strength of ice in the field.

\section{LITERATURE CITED}

Bender, J.A. (1957) Testing of a compacted snow runway. Journal of the Air Transport Division, American Society of Civil Engineers, 83 (paper 1324): 1-20. Borodkin, V.A., V.P. Gavrilo, S.M. Kovalev and G.A. Labedev (1992) Influence of structural anisotropy of sea ice on its mechanical and electrical properties. In Proceedings of Second International Offshore and Polar Engineering Conference, San Francisco, California. ISOPE, vol. 2, p. 670-674.

Brown, E.T., L.R. Richards and M.V. Barr (1977). Shearstrength characteristics of the Delaboleslates. In Proceedings of Conference on Rock Engineering, Newcastle University, vol. 1, p. 33-51.

Brown, R.L. and L.R. McKittrich (1992) An evaluation of micromechanical processes in deformation of sea icesinglecrystals. In Proceedings of IAHR Symposium, Banff, Alberta, Canada. International Association for Hydraulic Research, vol. 2, p. 1035-1046. Butkovich, T.R. (1954) Ultimate strength of ice. USA Snow Ice and Permafrost Research Establishment, Research Report 11.

Cannon, N.P. (1985) The influence of grain size on compressive strength of polycrystalline ice. M.S. Thesis, Thayer School of Engineering, Dartmouth College, Hạnover, New Hampshire.

Carter, D. (1970) Brittle fracture of snow ice. In Proceedings of IAHR Symposium, Reykjavik, Iceland. International Association for Hydraulic Research, paper 5.2, p. 1-8.

Cole, D.M. (1987) Strain-rate and grain size effects in ice. Journal of Glaciology, 33(115): 274-280.

Cole, D.M. (1979) Preparation of polycrystalline ice specimens for laboratory experiments. Cold $R e-$ gions Science and Technology, 1: 153-159.

Cox, G.F.N., J.A. Richter-Menge, W.F. Weeks, M. Mellor and H. Bosworth (1984) The mechanical properties of multiyear sea ice, PhaseI: Test results. USA Cold Regions Research and Engineering Laboratory, CRREL Report 84-9.

Eissa, E.A. and A. Kazi (1988) Relation between static and dynamic Young's moduli of rocks. International Journal of Rock Mechanics, Mining Science and Geomechanics, Abstracts, 25(6): 479-482. 
Frederking, R.M.W. and G.W. Timco (1989) Compressive behavior of Beaufort Sea ice under vertical and horizontal loading. In Proceedings of Third International Offshore Mechanics and Arctic Engineering Symposium (V.J. Lunardini,Ed.). American Society of Mechanical Engineers, no. 111, p. 145149.

Gow, A.J. (1975) Time-temperature dependence of sintering in perennial isothermal snowpacks. In Proceedings, Grindelwald Symposium, April 1974, Snow Mechanics. IAHS-AISH Publication 114, p. 25-41.

Haynes, F.D. (1979) Temperature effect on the uniaxial strength of ice. In POAC 79: Proceedings, Fifth International Conference on Port and Ocean Engineering under Arctic Conditions, 13-18 August, Trondheim, Norway. Trondheim University, vol.1, p. $667-681$.

Kirk, M.T. (1989) Estimation of lower bound properties from material test data. U.S. Navy David Taylor Research Center, Report DTRC-SME-88/ 63.

Kovacs, A. (1978) Axial double-point-load tests on snow and ice. USA Cold Regions Research and Engineering Laboratory, CRREL Report 78-1.

Kovacs, A. (1985) Apparent unconfined compressive strength of multiyear sea ice. In POAC 85: Proceedings, Eighth International Conference on Port and Ocean Engineering under Arctic Conditions, 7-14 September, Narssarssuaq, Greenland. DanishHydraulic Institute, Hörsholm, Denmark, vol. 1, p. 116127.

Kovacs, A., W.F. Weeks and F. Michittti (1969) Variation of some mechanical properties of polar snow vs. depth density. USA Cold Regions Research and Engineering Laboratory, Research Report 276.

Kovacs, A., F. Michitti and J.F. Kalafut (1977) Unconfined compression tests on snow-A comparative study. USA Cold Regions Research and Engineering Laboratory, Special Report 77-20.

Kuehn, G.A. and E.M. Schulson (1993) The mechanical properties of saline ice under uniaxial compression. In Proceedings of International Glaciological Society Symposium on Applied Ice and Snow Research, Rovaniemi, Finland. (See also Annals of Glaciology, preprint.)

Kuehn, G.A., E.M.Schulson, D.E. Jones and J. Zhang (1992) The compressive strength of ice cubes of different sizes. In Proceedings, 11th International Conference on Offshore Mechanics and Arctic Engineering, Calgary, Alberta, Canada (A. Ayorinde, N.K. Sinka, D.S. Sodhi and W.A. Nixon, Ed.), vol. 4, p. 349-356.
Lachance, J. and B. Michel (1988) Experimental study of the brittle behavior of iceberg ice. In POAC 77: Proceedings, Fourth International Conference on Port and Ocean Engineering under Arctic Conditions, 26-30 September, St. John's, Newfoundland. Memorial University of Newfoundland, vol. 3, p. 11-19.

Mellor, M. (1983) Mechanical behavior of ice. USA Cold Regions Research and Engineering.Laboratory, Monograph 83-1.

Peyton, H.R. (1966) Sea ice strength. Geophysical Institute, University of Alaska, Report No. UAG R-182.

Reichmuth, D.R. (1968) Point load testing of brittle materials to determine tensile strength and relative brittleness. In Proceedings of Ninth Symposium on Rock Mechanics, Golden, Colorado (N.E. Grosvenor and B.W. Paulding, Jr., Ed.), p. 134-159.

Richter-Menge,J.A. (1986) Comparison of the compressive behavior of natural and laboratory-grown saline ice. In Proceedings, International Workshop on Ice Penetration Technology, Hanover, New Hampshire. USA Cold Regions Research and Engineering Laboratory, Special Report 86-30, p. 331-350. Richter-Menge, J.A. (1991) Confined compressive strength of horizontal first-year sea ice samples. Transactions of the American Society of Mechanical Engineers, 113: 344-351.

Schulson, E.M. (1990) The brittle compressive fracture of ice. Acta Mettallurgica Mater, 38(10): 19631976.

Schulson, E.M. and N.P. Cannon (1984) The effect of grain size on the compressive strength of ice. In Proceedings of IAHR Symposium on Ice, Hamburg, Germany. International Association of Hydraulic Research, vol. 1, p. 29-38.

Schwarz, J. (1971) The pressure of floating icefields. In Proceedings of IAHR Symposium on Ice and its Action on Hydraulic Structures, Reykjavik, Iceland. International Association of Hydraulic Research, paper 63.

Schwarz, J., R. Frederking, V. Gavrito, I.G. Petov, K.I. Hirayama, M. Mellor, P. Tryde and K.D. Vaudrey (1981)Standardized testing methods for measuring mechanical properties of ice. Cold Regions Science and Technology, 4(3): 245-253.

Sinha, N.K. (1983) Field tests of compressive strength of first-year sea ice. Annals of Glaciology, 4: 253-259.

Smith, J.L. (1965) The elastic constants, strength and density of Greenland snow as determined from measurements of sonic velocity. USA Cold Regions Research and Engineering Laboratory, Technical Report 167. 
Timco, G.W. and R.M.W. Frederking (1990) Compressive strength of sea ice sheets. Cold Regions Science and Technology, 17: 227-240.

Timco, G. W. and R.M.W. Frederking (1991) Seasonal compressive strength of Beaufort Sea ice sheets. In Proceedings, Ice-Structure Interaction, IUTAM-IAHR Symposium, St. John's, Newfoundland (S. Johnes, R.F. McKenna, J. Tillotson and I. Jordann, Ed.), p. 267-282.

Wang, Y.S. (1979) Sea ice properties. Technical seminar on Alaskan Beaufort Sea Gravel Island
Design, Exxon Company, Houston, Texas.

Weeks, W.F. and S.F. Ackley (1982) The growth, structure and properties of sea ice. USA Cold Regions Research and Engineering Laboratory, Monograph 82-1.

Wolfe, L.H. and J.O. Thiem (1964) Physical properties of frozen soil and ice. Journal Society of Petroleum Technology, 4(1): 67-72.

Yamaguchi, U.(1970) Test pieces required to determine the strength of rock. International Journal of Rock Mechanics and Mining Sciences, 7(2): 209-227. 
Public reporting burden for this collection of information is estimated to average 7 hour per response, including the time for reviewing instructions, searching existing data sources, gathering and maintaining the data needed, and completing and reviewing the collection of information. Send comments regarding this burden estimate or any other aspect of this collection of information, including suggestion for reducing this burden, to Washington Headquarters Services, Directorate for Information Operations and Reports, 1215 Jefferson Davis Highway, Suite 1204, Arlington, VA 22202-4302, and to the Office of Management and Budget, Paperwork Reduction Project (0704-0188), Washington, DC 20503.

\begin{tabular}{|l|l|l|}
\hline 1. AGENCY USE ONLY (Leave blank) & $\begin{array}{c}\text { 2. REPORT DATE } \\
\text { December } 1993\end{array}$ & 3. REPORT TYPE AND DATES COVERED \\
\hline
\end{tabular}

4. TITLE AND SUBTITLE

Axial Double-Ball Test Versus the Uniaxial Unconfined Compression Test

for Measuring the Compressive Strength of Freshwater and Sea Ice

6. AUTHORS

Austin Kovacs

7. PERFORMING ORGANIZATION NAME(S) AND ADDRESS(ES)

8. PERFORMING ORGANIZATION

REPORT NUMBER

U.S. Army Cold Regions Research and Engineering Laboratory

72 Lyme Road

CRREL Report 93-25

Hanover, New Hampshire 03755-1290

9. SPONSORING/MONITORING AGENCY NAME(S) AND ADDRESS(ES)

10. SPONSORING/MONITORING

AGENCY REPORT NUMBER

11. SUPPLEMENTARY NOTES

12a. DISTRIBUTION/AVAILABILITY STATEMENT

12b. DISTRIBUTION CODE

Approved for public release; distribution is unlimited.

Available from NTIS, Springfield, Virginia 22161.

13. ABSTRACT (Maximum 200 words)

Axial double-ball load tests were made on freshwater ice and first-year and multiyear sea ice. From this simple test method the apparent unconfined compressive strength of the ice was determined. These strength results were compared with those obtained from the complex and costly uniaxial unconfined compression test made on similar ice at a strain rate of $10^{-3} \mathrm{~s}^{-1}$. The scatter in the test data and the average ice strength obtained from both test methods were similar. The findings indicate that the expedient axial double-ball load test is well suited for determining the unconfined compressive strength of ice, especially in the field where the demanding sample preparation requirements needed for unconfined compression test samples cannot be met.

\begin{tabular}{|c|c|c|c|}
\hline \multirow{2}{*}{$\begin{array}{l}\text { 14. SUBJECT TERMS } \\
\text { Compressive strength } \\
\text { Freshwater ice }\end{array}$} & \multirow{2}{*}{$\begin{array}{l}\text { Ice } \\
\text { Ice strength }\end{array}$} & & \multirow{2}{*}{\begin{tabular}{|l} 
15. NUMBER OF PAGES \\
16. PRICE CODE
\end{tabular}} \\
\hline & & & \\
\hline $\begin{array}{l}\text { 17. SECURITY CLASSIFICATION } \\
\text { OF REPORT }\end{array}$ & $\begin{array}{l}\text { 18. SECURITY CLASSIFICATION } \\
\text { OF THIS PAGE }\end{array}$ & $\begin{array}{l}\text { 19. SECURITY CLASSIFICATION } \\
\text { OF ABSTRACT }\end{array}$ & 20. LIMITATION OF ABSTRACT \\
\hline UNCLASSIFIED & UNCLASSIFIED & UNCLASSIFIED & UL \\
\hline
\end{tabular}

